\title{
Tsunami evacuation plans for future megathrust earthquakes in Padang, Indonesia, considering stochastic earthquake scenarios
}

\author{
Ario Muhammad ${ }^{1,2}$, Katsuichiro Goda ${ }^{1}$, Nicholas A. Alexander ${ }^{1}$, Widjo Kongko ${ }^{3}$, and Abdul Muhari ${ }^{4}$ \\ ${ }^{1}$ Department of Civil Engineering, University of Bristol, Bristol, BS8 1TR, UK \\ ${ }^{2}$ Department of Civil Engineering, University of Narotama, Surabaya, 60117, Indonesia \\ ${ }^{3}$ Agency for the Assessment \& Application of Technology (BPPT), Yogyakarta, 55281, Indonesia \\ ${ }^{4}$ Directorate General for Marine Spatial Management, Ministry of Marine Affairs and Fisheries, Jakarta, 10110, Indonesia
}

Correspondence: Ario Muhammad (ario.muhammad@bristol.ac.uk)

Received: 14 February 2017 - Discussion started: 4 May 2017

Revised: 2 October 2017 - Accepted: 8 November 2017 - Published: 12 December 2017

\begin{abstract}
This study develops tsunami evacuation plans in Padang, Indonesia, using a stochastic tsunami simulation method. The stochastic results are based on multiple earthquake scenarios for different magnitudes $\left(M_{\mathrm{w}} 8.5,8.75\right.$, and 9.0) that reflect asperity characteristics of the 1797 historical event in the same region. The generation of the earthquake scenarios involves probabilistic models of earthquake source parameters and stochastic synthesis of earthquake slip distributions. In total, 300 source models are generated to produce comprehensive tsunami evacuation plans in Padang. The tsunami hazard assessment results show that Padang may face significant tsunamis causing the maximum tsunami inundation height and depth of 15 and $10 \mathrm{~m}$, respectively. A comprehensive tsunami evacuation plan - including horizontal evacuation area maps, assessment of temporary shelters considering the impact due to ground shaking and tsunami, and integrated horizontal-vertical evacuation time maps - has been developed based on the stochastic tsunami simulation results. The developed evacuation plans highlight that comprehensive mitigation policies can be produced from the stochastic tsunami simulation for future tsunamigenic events.
\end{abstract}

\section{Introduction}

Tsunami hazard and risk assessments have become an important issue in tsunami-prone regions especially after the 2004 Aceh-Andaman earthquake $\left(M_{\mathrm{w}}\right.$ 9.15) and the 2011 Tōhoku earthquake $\left(M_{\mathrm{w}} 9.0\right)$. Significant risk mitigation ef- forts have been made in recent years in high-risk countries, such as Japan, USA, Chile, New Zealand, and Indonesia (Schlurmann et al., 2010; Wood et al., 2014; Mueller et al., 2015; Raby et al., 2015). Even though Japan is a welldeveloped country with comprehensive tsunami defense systems, the 2011 Tōhoku tsunami still caused significant damage, causing economic loss of $\sim$ USD 365 billion and fatalities of $\sim 20000$ people (Kazama and Noda, 2012). Globally, preparedness systems for earthquake and tsunami hazards need to be improved to reduce the economic and social impact of future tsunamigenic earthquake events (Scheer et al., 2011; Wood et al., 2012). Among the tsunami-prone countries, Indonesia is in one of the most seismically active zones: there were 34 major tsunamigenic events in the last 20 years (USGS, 2015). Past paleogeodetic, paleotsunami, and geodetic investigations (e.g., Nalbant et al., 2005; Sieh et al., 2008) indicate that the Mentawai segment of the Sunda subduction zone (see Fig. 1a) can host large tsunamigenic events $\left(M_{\mathrm{W}}>8.5\right)$ with a recurrence period of about 200 years. The last major tsunamigenic earthquakes in this region were the 1797 and 1833 events (Natawidjaja et al., 2006), while two recent events, $M_{\mathrm{w}} 8.4$ and $M_{\mathrm{w}} 7.9$, occurred near Bengkulu on 12 and 13 September 2007 (see Fig. 1a). A study by Konca et al. (2007) concluded that the recent earthquakes released far smaller amounts of slip in comparison with the accumulated slip since 1833 and, hence, the potential of a large tsunamigenic event originated from this source remains high.

Padang is a home of more than 850000 and is one of the most urbanized cities in western Sumatra. The 2004 Aceh-Andaman tsunami did not significantly affect this re- 
gion since the earthquake source was $>1200 \mathrm{~km}$ far away (Natawidjaja et al., 2006; Meltzner et al., 2006; Briggs et al., 2006). However, it is located along the coast of Sumatra Island, directly facing the Mentawai segment of the Sunda subduction zone (see Fig. 1a). Consequently, the potential impact of the future tsunami may be significant in this area. In addition, with the low-lying plain topographic features in Padang, the probability of large inundated areas and large inundation depths is also high (Borrero et al., 2006; Muhari et al., 2010, 2011). In the past, two types of earthquake source scenarios have been mainly considered to develop tsunami risk mitigation plans in Padang: deterministic scenarios (Borrero et al., 2006; Schlurmann et al., 2010; Muhari et al., 2010, 2011) and probabilistic scenarios (McCloskey et al., 2008; Griffin et al., 2016). These two methods have both advantages and disadvantages. For instance, the deterministic approach is more communicable to the authorities for developing post-disaster recovery and mitigation plans (McGuire, 2001). However, implementation of deterministic scenarios may oversimplify the tsunami hazards and risks, leading to imprecise mitigation plans (Griffin et al., 2015; Mueller et al., 2015). In contrast, the probabilistic approach requires the proper consideration of regional earthquake characteristics, including uncertainties in the earthquake rupture size, its focal mechanism, and the depth and spatial heterogeneity of the earthquake slip. Therefore, extensive and detailed data regarding the regional seismological characteristics are essential to developing the probabilistic scenarios. In previous investigations, those regional earthquake characteristics have not been properly taken into account (McCloskey et al., 2008; Griffin et al., 2016). Recently, Muhammad et al. (2016) have evaluated the tsunami potential in Padang by developing the stochastic tsunami simulation method, allowing us to generate numerous scenarios of stochastic tsunami hazard. However, that work was limited to evaluating the tsunami hazards offshore and near the coast only because of the gross bias of the elevation model in Padang (Griffin et al., 2015) and, therefore, was not suitable to carry out rigorous assessment of tsunami mitigation systems. The gross bias of the elevation model in Padang is due to the use of global digital elevation model (DEM; i.e., GDEM2) as the elevation data for the stochastic tsunami simulation. The absolute vertical errors of global DEM (e.g., GDEM2 and SRTM1) are in the range from 5 to $10 \mathrm{~m}$, resulting in inaccurate prediction of the inundation footprints especially in coastal areas (Sanders, 2007; Gallegos, 2009; Lewis et al., 2013; Griffin et al., 2015). Thereby, this work also highlights the effect of DEM on inundation modeling in Padang areas, which has not been studied in the previous investigations.

Moreover, an effective tsunami evacuation plan should combine both horizontal evacuation to high grounds and vertical evacuation to designated tsunami-resistant shelters (FEMA P-646, 2012). In the coastal areas where people can afford a relatively short evacuation time (less than $30 \mathrm{~min}$ ),
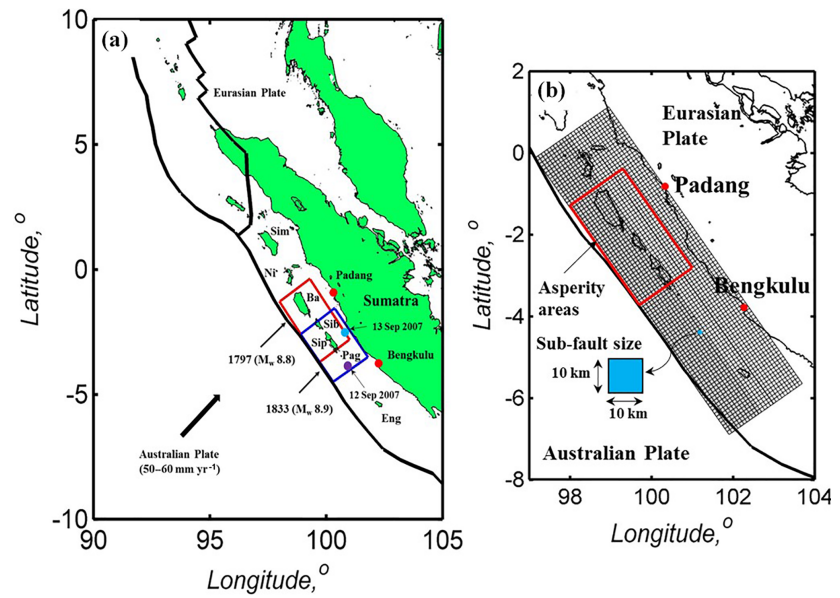

Figure 1. (a) Significant seismic events in the Mentawai segment of the Sunda subduction zone (Sim: Simeulue; Ni: Nias; Ba: Batu; Sib: Sibereut; Sip: Sipora; Pag: Pagai Islands; Eng: Enggano). (b) Fault plane of the Mentawai segment source along with the asperity.

the vertical evacuation is highly desirable (Scheer et al., 2012; Wood et al., 2014). In previous investigations, the tsunami arrival time in Padang was estimated to be 2030 min (Borrero et al., 2006; McCloskey et al., 2008; Schlurmann et al., 2010; Muhammad et al., 2016) and, therefore, effective vertical evacuation plans are needed in this region. In Padang, 23 tsunami evacuation shelters (TESs) have been planned and built in the urban areas near the coastal line. However, an extensive assessment of the TESs in Padang during the tsunami event was not conducted by the previous studies (Schlurmann et al., 2010; Muhari et al., 2010, 2011; Imamura et al., 2011). Only horizontal evacuation time maps to safe areas were provided in Schlurmann et al. (2010), excluding seismic and tsunami vulnerability assessments of TESs. Subsequently, it is important to assess the TESs considering impacts of ground shaking and tsunami in Padang as part of future tsunami mitigation planning. The results of the TES assessment can be further used to develop integrated horizontal-vertical tsunami evacuation maps.

Building upon the previous studies, this study develops tsunami evacuation plans in Padang based on the stochastic tsunami simulation method. This approach generates multiple earthquake scenarios by considering the uncertainties of the earthquake source parameters and slip distributions, both of which have major influence on the tsunami hazards. Hence, it is suitable to estimate the tsunami hazard level in Padang. Regional seismological characteristics are taken into account in generating stochastic earthquake scenarios based on the finite-fault models of the past earthquakes in the Sunda subduction zone. In addition, a $5 \mathrm{~m}$ high-resolution DEM of Padang (DEM5) developed by the German-Indonesian Tsunami Early Warning System (GITEWS) project and Indonesian research institutions is adopted as land elevation data for tsunami simulation. The combination of stochastic 


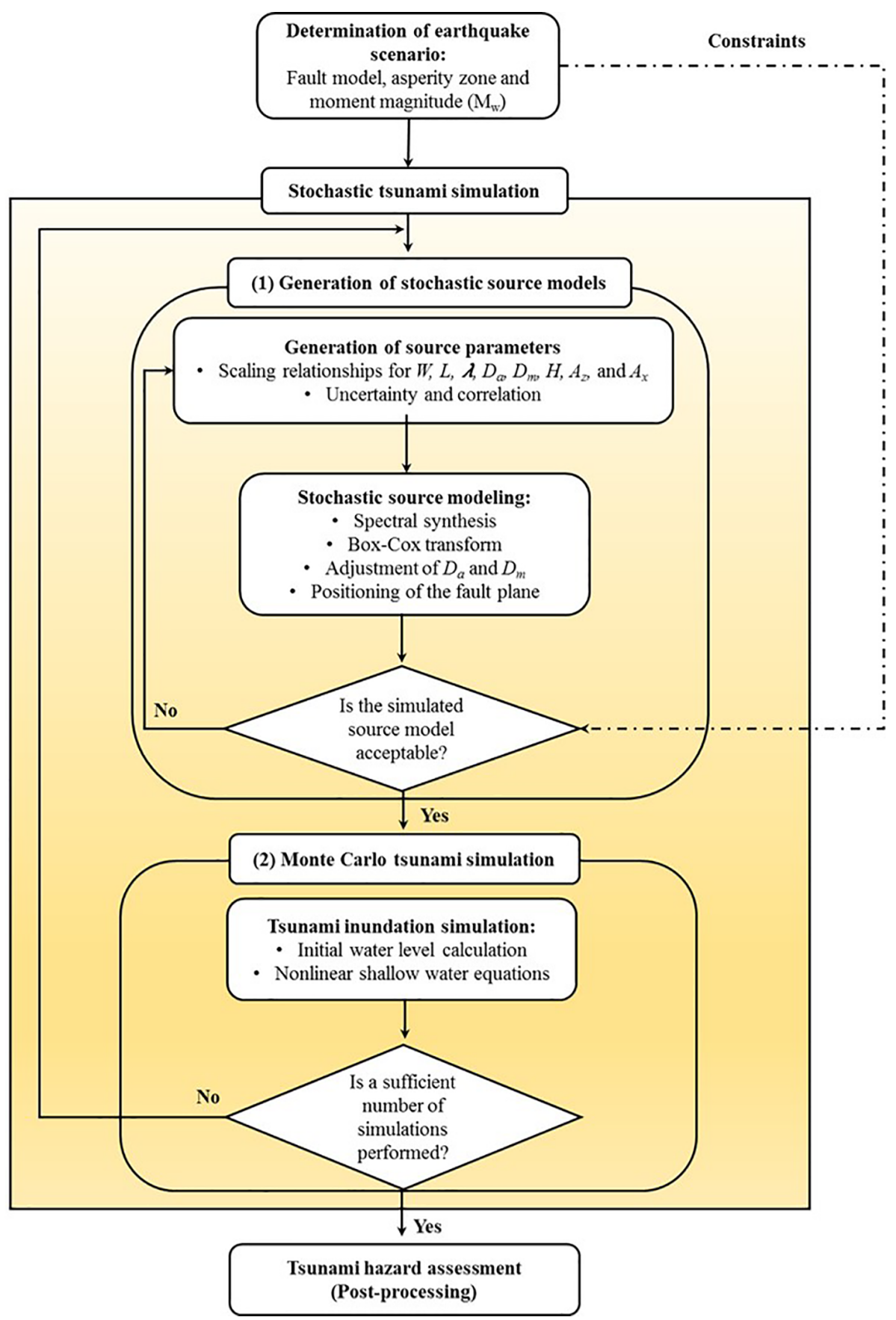

Figure 2. Procedures of stochastic tsunami simulation.

tsunami inundation modeling and the high-resolution DEM significantly improves the accuracy of tsunami inundation modeling in Padang. Subsequently, the tsunami mitigation plans in Padang, i.e., tsunami inundation maps, TES assessments considering impacts due to ground shaking and tsunami, and integrated horizontal-vertical evacuation time maps, are produced based on inundation depths estimated from the stochastic tsunami simulations. The development of such tsunami mitigation systems in Padang will overcome the limitations of the previous works and will contribute to improve the tsunami preparedness in the face of future catastrophic events. 


\section{Methodology}

\subsection{Tsunami modeling}

\subsubsection{Earthquake scenario selection}

The stochastic tsunami simulation method (Muhammad et al., 2016) is adopted to estimate the tsunami hazard level in Padang. To generate earthquake source model stochastically, earthquake scenarios in terms of magnitude and source region need to be set up in advance. An appropriate model of fault rupture zone including geometry of the fault plane and asperity regions is then defined (see Fig. 2). The geometry is essential to outlining the earthquake source zone, whilst a so-called asperity zone determines the areas of concentrated slips within the fault plane. In general, modeling an earthquake rupture process in terms of earthquake source and asperity zones for the future tsunamigenic earthquakes in the Mentawai-Sunda region is complicated and has significant uncertainty (Natawidjaja, 2006; Griffin et al., 2016). In this study, the future earthquake source area in the Mentawai segment is defined using the fault rupture areas of the historical subduction earthquakes in the Sunda subduction zone (see Muhammad et al., 2016, for details).

Firstly, a generic fault model covering the entire region of the Mentawai segment with a length of $920 \mathrm{~km}$ and width of $250 \mathrm{~km}$ is constructed (see Fig. 1b). Numerous megathrust earthquakes can be further generated within the generic fault model. This generic fault plane is consistent with the results of extensive geodetic, paleogeodetic, paleoseismic, and numerical studies (Nalbant et al., 2005; Natawidjaja et al., 2006; Chlieh et al., 2008; Sieh et al., 2008; Philibosian et al., 2014). The depth of fault plane ranges from 3 to $50 \mathrm{~km}$ with a regular strike angle (i.e., $325^{\circ}$ ). The dip angle varies from $8^{\circ}$ to $16^{\circ}$ depending on the depth; e.g., the dip angle becomes steeper as the depth increases. The properties of the fault plane are consistent with the previous investigations. For instance, the depth is comparable with the source models of the past Mentawai-Sunda subduction earthquakes and the strike and dip angles are in line with the slab models of the Sunda subduction zone developed by the USGS (Newman et al., 2011; Satake et al., 2013; Philibosian et al., 2014; Yue et al., 2014; Hayes et al., 2009, 2012). In addition, to stochastically generate the earthquake sources, the fault plane is divided into $10 \mathrm{~km}$ by $10 \mathrm{~km}$ sub-faults (see Fig. $1 \mathrm{~b}$ ).

Secondly, within the fault plane of the source zone, asperity zones are set up. The asperity zones reflect the regional seismological knowledge of earthquake ruptures. Understanding the rupture process of past seismicity in the Mentawai segment is essential to determine the asperity zones. Based on the past seismicity, the most likely asperity zones for the future tsunamigenic earthquake events in the Mentawai segment are located in the rupture areas of the 1797 and 1833 events since these two events were the last tsunamigenic earthquake events in the Mentawai-Sunda region (Borrerro et al., 2006; Natawidjaja et al., 2006; McCloskey et al., 2008). A $300 \mathrm{~km}$ long area that extended from 0.5 to $3.2^{\circ} \mathrm{S}$ of the Mentawai segment (see Fig. 1a) was determined as the asperity zone of the 1797 event based on the geodetic and paleogeodetic measurements. In contrast, a $320 \mathrm{~km}$ long area that extended from 2.1 to $5^{\circ} \mathrm{S}$ (see Fig. 1a) was inferred as the asperity zone of the 1833 event (Natawidjaja et al., 2006; Philibosian et al., 2014). Note that the 1797 event produced a more significant tsunami impact in Padang than the 1833 event (Borrero et al., 2006; Natawidjaja et al., 2006; McCloskey et al., 2008). Consequently, in this study, the 1797 asperity zone is adopted to generate the future stochastic earthquake source models. In addition, in terms of selected magnitude scenarios, three scenario magnitudes are considered: $M_{\mathrm{w}} 8.5, M_{\mathrm{W}} 8.75$, and $M_{\mathrm{w}} 9.0$. The magnitude $M_{\mathrm{w}} 8.5$ is used as the minimum scenario because the tsunami hazard produced from the magnitude below this level, e.g., $M_{\mathrm{w}} 8.25$ and $M_{\mathrm{w}} 8.0$, is relatively small (less than $1 \mathrm{~m}$ wave height in the coastal areas; see Muhammad et al., 2016). The maximum magnitude scenario $\left(M_{\mathrm{w}} 9.0\right)$ is selected based on paleogeodetic, geodetic, and paleotsunami studies (Zachariasen et al., 1999; Natawidjaja et al., 2006; Sieh et al., 2008); they indicated that the accumulated slip in the Mentawai segment of the Sunda subduction zone may generate tsunamigenic earthquakes with a magnitude range from $M_{\mathrm{w}} 8.8$ to $M_{\mathrm{w}} 9.0$.

\subsubsection{Stochastic tsunami simulation}

The stochastic tsunami simulation involves two main processes: (1) stochastic earthquake source model generation and (2) Monte Carlo tsunami simulation (see Fig. 2). For generating realistic source models stochastically, regional seismological characteristics of Sumatra are analyzed. It is carried out by estimating earthquake source properties including geometry (fault length, $L$, and fault width, $W$ ), slip statistics (mean slip, $D_{\mathrm{a}}$, maximum slip, $D_{\mathrm{m}}$, and Box-Cox parameter, $\lambda$ ), and spatial heterogeneity parameters (correlation length along strike direction, $A_{x}$, correlation length along dip direction, $A_{z}$, and Hurst number, $H$ ). Those parameters are calculated using the effective dimension analysis method (Mai and Beroza, 2000), Box-Cox analysis (Goda et al., 2014), and spectral analysis (Mai and Beroza, 2002); see Muhammad et al. (2016) for the details.

Subsequently, the calculated regional earthquake source parameters are compared against the global scaling relationships developed by Goda et al. (2016) to examine the adequacy of the global models to the Mentawai-Sunda region. Muhammad et al. (2016) concluded that the regional earthquake source parameters calculated from the 19 past Sunda earthquakes are in good agreement with these scaling relationships; subsequently, the global models are adopted in this study. A set of 100 source models is then generated for each magnitude. Therefore, the total number of the stochastic earthquake slip models used in this study is 300 . 
For a given stochastic source model, the initial deformation of the seabed is calculated by considering both horizontal and vertical displacements of the seafloor using Okada (1985) and Tanioka and Satake (1996). Tsunami modeling is then carried out by solving nonlinear shallow water equations with run-up (Eqs. 1 to 3). A finite-difference method implementing a staggered leap-frog scheme is adopted to solve the governing equations (Goto et al., 1997). In addition, in Goto et al. (1997) the moving boundary approach developed by Iwasaki and Mano (1979) is used for inundation modeling. This method has been successfully used to run the tsunami simulation in several regions, including Padang, Indonesia, Mexico, and Japan (Muhari et al., 2010, 2011; Goda et al., 2014; Mori et al., 2017).

$$
\begin{aligned}
& \frac{\partial \eta}{\partial t}+\frac{\partial M}{\partial x}+\frac{\partial N}{\partial y}=0 \\
& \frac{\partial M}{\partial t}+\frac{\partial}{\partial x}\left(\frac{M^{2}}{D}\right)+\frac{\partial}{\partial y}\left(\frac{M N}{D}\right)+g D \frac{\partial \eta}{\partial x} \\
& +\frac{g n^{2}}{D^{7 / 3} M \sqrt{M^{2}+N^{2}}=0} \\
& \frac{\partial N}{\partial t}+\frac{\partial}{\partial x}\left(\frac{M N}{D}\right)+\frac{\partial}{\partial y}\left(\frac{N^{2}}{D}\right)+g D \frac{\partial \eta}{\partial y} \\
& \quad+\frac{g n^{2}}{D^{7 / 3}} N \sqrt{M^{2}+N^{2}}=0
\end{aligned}
$$

where $D=h+\eta$ representing the total water depth, in which $h$ and $\eta$ are the water depth and the tsunami height above the reference sea level, respectively; $g$ is the gravitational acceleration; and $n$ is the Manning's roughness coefficient. The discharge fluxes (i.e., $M$ and $N$ ) are obtained from the integration of velocity in $x(u)$ and $y(v)$ directions over the water depth (Eqs. 4 and 5).

$$
\begin{aligned}
& M=\int_{-h}^{\eta} u \mathrm{~d} z=u(h+\eta)=u D \\
& N=\int_{-h}^{\eta} v \mathrm{~d} z=v(h+\eta)=v D
\end{aligned}
$$

Moreover, DEM and bathymetry datasets are developed to run the stochastic tsunami simulation. In this study, the DEM5 is adopted as land elevation data (see Sect. 2.1.3 for the details), whilst for bathymetry the GEBCO2014 dataset (http://www.gebco.net/data_and_products/gridded_ bathymetry_data/) and a $3 \mathrm{~m}$ Padang bathymetry dataset are combined. Four nested grids, i.e., 1350, 450, 150, and $50 \mathrm{~m}$, produced from linear interpolation of these datasets, are used to run the tsunami simulation. A roughness coefficient of $0.025 \mathrm{~m}^{-1 / 3} \mathrm{~s}$ for water and $0.06 \mathrm{~m}^{-1 / 3} \mathrm{~s}$ for land are adopted to model the surface roughness effects on tsunami flows (Griffin et al., 2015). By assuming instantaneous fault rupture, the duration and time step of tsunami simulation are then defined as $2 \mathrm{~h}$ and $0.5 \mathrm{~s}$, respectively. It satisfies the Courant-Friedrichs-Lewy criterion for the bathymetry and elevation data for the Mentawai region. The Monte Carlo tsunami simulation is finally performed using different stochastic earthquake source scenarios.

\subsubsection{Effect of digital elevation model on tsunami inundation modeling}

An accurate DEM is essential for tsunami simulation and is particularly critical in calculating tsunami inundation depths. Recently, several international organizations and consortia have produced global DEM datasets, including GTOPO30, SRTM30, SRTM3v2, SRTM3v4, SRTM1, and GDEM2. Currently, the SRTM1 (https://lta.cr.usgs.gov/SRTM1Arc) and GDEM2 (https://asterweb.jpl.nasa.gov/gdem.asp) with a resolution of $1 \operatorname{arcsec}(\sim 30 \mathrm{~m})$ are the best available global DEM datasets and widely used for land elevation data in tsunami simulation (Satake et al., 2013; Yue et al., 2014). In general, the range of numerical processes employed in the compilation of DEMs can have a major influence on the magnitude of errors. Both epistemic and aleatory noise can be present. For instance, the average vertical errors of SRTM1 and GDEM2 are in the range of $10 \mathrm{~m}$ (Tachikawa et al., 2011; Satge et al., 2015). Because tsunami evacuation plans are mainly developed based on the inundation results, the effect of DEM on tsunami inundation modeling is assessed before presenting the main tsunami simulation results in Sect. 3. In this study, the baseline DEM is the local DEM5. The DEM5 dataset was developed from GPS measurements and highresolution satellite imagery to produce the DEM profile of Padang, particularly near the coastal line (see Fig. 4a). A vertical error of $0.2 \mathrm{~m}$ was found in this dataset. Hence, the DEM5 is reliable to represent the land elevation of Padang (Taubenbock et al., 2009; Schlurmann et al., 2010).

In this section, two global DEM datasets, i.e., SRTM1 and GDEM2, are adopted to study the effect of DEMs on tsunami inundation modeling in the Padang areas (see Fig. $4 \mathrm{~b}$ and c). The elevation differences between the DEM5 and the two global datasets (i.e., SRTM1 and GDEM2) are firstly assessed and discussed. Then, the differences on tsunami inundation results from these three datasets are further presented. Note that the bathymetry dataset (GEBCO2014) is common for all three cases. The considered source model is one realization from the 100 stochastic earthquake sources in the Mentawai-Sunda zone for the $M_{\mathrm{W}} 9.0$ scenario. This is shown in Fig. 3b; the maximum slip of the chosen model reaches $25 \mathrm{~m}$ with the fault size of $450 \mathrm{~km}$ in length and $250 \mathrm{~km}$ in width.

The elevation differences of the SRTM1 and the GDEM2 datasets with respect to the reference DEM5 data are presented in Fig. 5a and b, respectively. The elevation differences are calculated by taking the elevation differences between the global DEM datasets (i.e., SRTM1 and GDEM2) and the reference data. Several statistics, including the mini- 

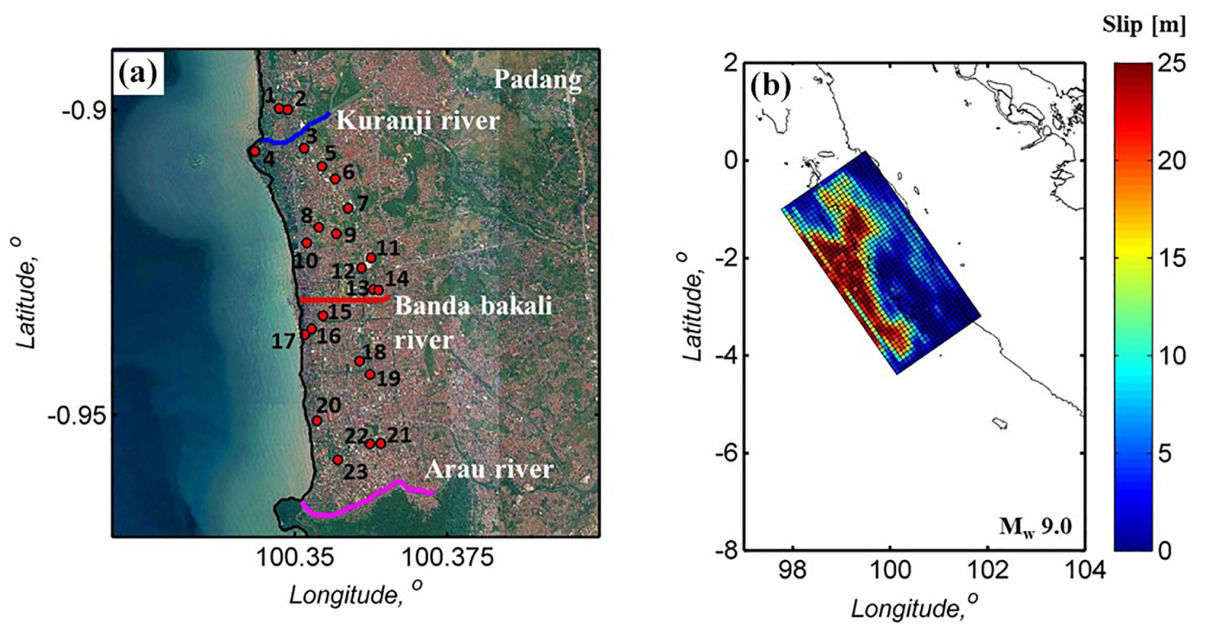

Figure 3. (a) Tsunami evacuation shelters in Padang. (b) Earthquake source models to study the effect of DEM on tsunami simulation.
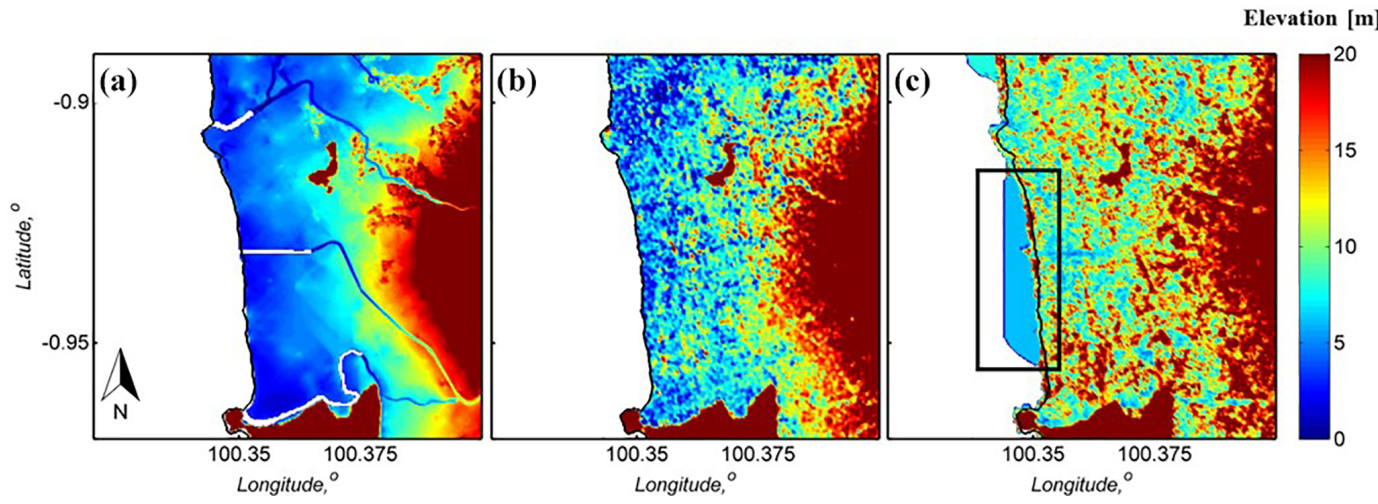

Figure 4. Digital elevation model for Padang: (a) DEM5, (b) SRTM1, and (c) GDEM2.

Table 1. Statistics of elevation differences between global DEM datasets (i.e., SRTM1 and GDEM2) and the reference data (DEM5).

\begin{tabular}{lrrrrr}
\hline DEM & $\begin{array}{r}\text { Min } \\
(\mathrm{m})\end{array}$ & $\begin{array}{r}\text { Max } \\
(\mathrm{m})\end{array}$ & $\begin{array}{r}\text { Mean diffe- } \\
\text { rence }(\mathrm{m})\end{array}$ & $\begin{array}{r}\text { Absolute mean } \\
\text { difference }(\mathrm{m})\end{array}$ & $\begin{array}{r}\text { RMSE } \\
(\mathrm{m})\end{array}$ \\
\hline DEM5 & 0 & 280 & - & - & - \\
SRTM1 & 0 & 273 & 1.48 & 3.13 & 4.27 \\
GDEM2 & 0 & 268 & 3.96 & 5.69 & 7.46 \\
\hline
\end{tabular}

mum, maximum, mean difference, absolute mean difference, and root mean square error (RMSE) values, are calculated for each global DEM dataset and presented in Table 1. The difference with the reference data in terms of maximum elevation value for SRTM1 is $7 \mathrm{~m}$. This is smaller than $12 \mathrm{~m}$ for GDEM2. The other three statistical scores for SRTM1, i.e., the mean difference, the absolute mean difference, and the RMSE, are also smaller than GDEM2. For instance, the RMSE of SRTM1 is $4.27 \mathrm{~m}$, which is smaller than $7.46 \mathrm{~m}$ for GDEM2. In general, SRTM1 performs better than GDEM2. However, the RMSE scores of 4.27 and $7.46 \mathrm{~m}$ may lead to inaccurate modeling of inundation in land, especially in lowlying areas where the elevation is below $10 \mathrm{~m}$.

Subsequently, to evaluate the effect of DEMs on inundation modeling, Fig. 7 illustrates inundation maps in Padang based on three different DEMs, i.e., DEM5 (Fig. 7a), SRTM1 (Fig. 7b), and GDEM2 (Fig. 7c). Total inundation areas are also presented in Fig. 7. The inundation maps indicate that the global DEM datasets (i.e., SRTM1 and GDEM2) underestimate the inundation areas significantly. The total inundation area of SRTM1 is less than a half of DEM5 (i.e., $7.32 \mathrm{~km}^{2}$ in comparison to $16.04 \mathrm{~km}^{2}$ for DEM5). In contrast, GDEM2 performs worse than SRTM1 with only $0.74 \mathrm{~km}^{2}$ of total inundation area. The inundation difference for SRTM1 is mainly because of relatively high elevation differences $(\sim 5 \mathrm{~m})$ between SRTM1 and DEM5 near the coastal region (see Fig. 5a). Moreover, for GDEM2, the significant differences are mainly due to the overlapping land areas in the seaside area of the GDEM2 dataset which prevent the tsunami flow to go further in land (see black rectangle in Fig. 4c). In addition, significant differences of inundation areas found in the GDEM2 dataset are also due to high 


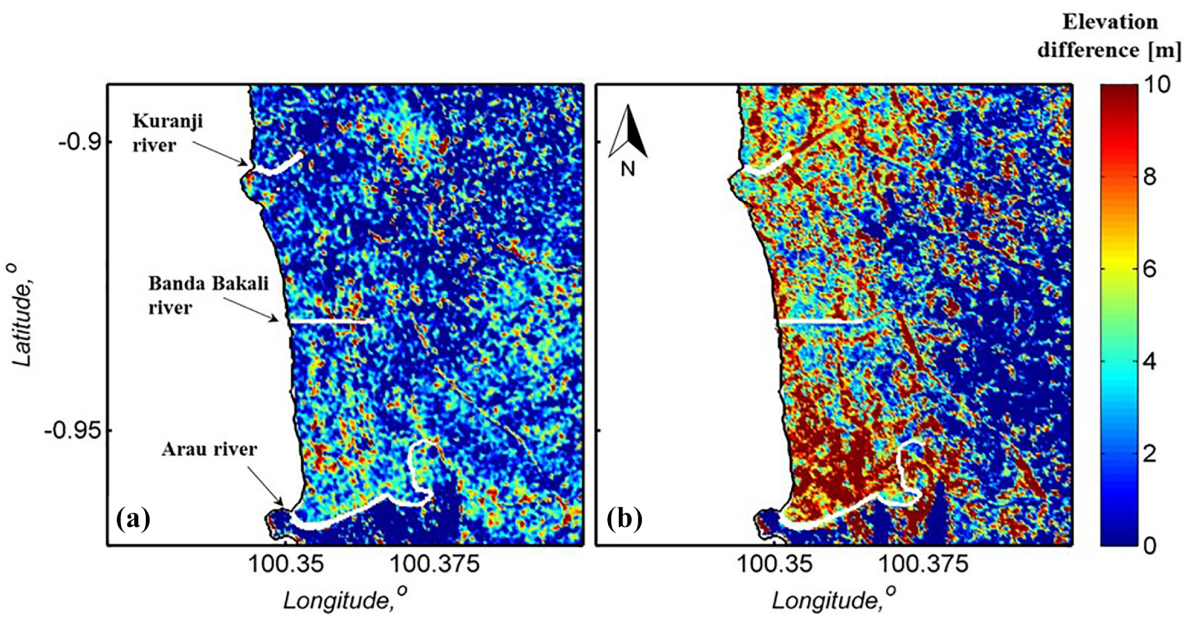

Figure 5. Elevation differences of global DEM datasets with respect to DEM5: (a) SRTM1 and (b) GDEM2.

Table 2. Tsunami evacuation shelters in Padang.

\begin{tabular}{|c|c|c|c|c|c|c|c|}
\hline \multirow[t]{2}{*}{ No. } & \multirow[t]{2}{*}{ Name of the shelter } & \multirow{2}{*}{$\begin{array}{l}\text { Capacity } \\
\text { (persons) }\end{array}$} & \multicolumn{2}{|c|}{ Location } & \multirow{2}{*}{$\begin{array}{l}\text { Maximum } \\
\text { height }(\mathrm{m})\end{array}$} & \multirow{2}{*}{$\begin{array}{r}\text { Number of } \\
\text { floors }\end{array}$} & \multirow{2}{*}{$\begin{array}{r}\text { Evacuation } \\
\text { area }\left(\mathrm{m}^{2}\right.\end{array}$} \\
\hline & & & Longitude & Latitude & & & \\
\hline 1 & Sport center of Universitas Negeri Padang (UNP) & 1500 & 100.3474 & -0.89979 & 10 & 1 & 2475 \\
\hline 2 & Art building of UNP & 2000 & 100.3488 & -0.89998 & 20 & 5 & 3300 \\
\hline 3 & DPRD province building & 2000 & 100.3515 & -0.90628 & 15 & 3 & 3300 \\
\hline 4 & Post-graduate building of Universitas Bung Hatta (UBH) & 2000 & 100.3434 & -0.90677 & 15 & 4 & 3300 \\
\hline 5 & Al-Azhar primary school & 1100 & 100.3544 & -0.90924 & 10 & 3 & 1815 \\
\hline 6 & BPK office of West Sumatra & 2000 & 100.3566 & -0.91127 & 20 & 4 & 3300 \\
\hline 7 & Office of Kanwil Ditjen Perbendaharaan & 2000 & 100.3587 & -0.9161 & 15 & 3 & 3300 \\
\hline 8 & Senior High School 1 of Padang & 1400 & 100.3539 & -0.91923 & 10 & 3 & 2310 \\
\hline 9 & Junior High School 25 of Padang & 1000 & 100.3568 & -0.92025 & 10 & 3 & 1650 \\
\hline 10 & Senior Vocational High School 5 of Padang & 3000 & 100.3519 & -0.92178 & 10 & 3 & 4950 \\
\hline 11 & Grand Mosque of West Sumatra & 4000 & 100.3625 & -0.92423 & 47 & 2 & 6600 \\
\hline 12 & BAPPEDA province office & 1500 & 100.3609 & -0.92589 & 15 & 3 & 2475 \\
\hline 13 & Ibis hotel of Padang & 3000 & 100.3629 & -0.9294 & 52 & 13 & 4950 \\
\hline 14 & PrasJal office of West Sumatra Province & 5000 & 100.3637 & -0.92953 & 15 & 4 & 8250 \\
\hline 15 & Elementary School 24 of Purus & 3000 & 100.3546 & -0.93371 & 10 & 3 & 4950 \\
\hline 16 & Mercure Hotel of Padang & 4000 & 100.3527 & -0.9359 & 30 & 8 & 6600 \\
\hline 17 & RUSUNAWA & 3200 & 100.3516 & -0.93681 & 15 & 5 & 5280 \\
\hline 18 & Governor office of West Sumatra & 3500 & 100.3606 & -0.94116 & 20 & 4 & 5775 \\
\hline 19 & Office of Bank Indonesia & 1000 & 100.3623 & -0.94336 & 10 & 2 & 1650 \\
\hline 20 & Nurul Haq mosque & 4000 & 100.3536 & -0.95091 & 22 & 5 & 6600 \\
\hline 21 & Grand Zuri Padang Hotel & 3000 & 100.3641 & -0.95467 & 25 & 6 & 4950 \\
\hline 22 & Nurul Iman mosque & 1000 & 100.3623 & -0.95473 & 10 & 2 & 1650 \\
\hline 23 & Grand Inna Muara Hotel & 4000 & 100.357 & -0.95734 & 25 & 6 & 6600 \\
\hline
\end{tabular}

RMSE $(7.42 \mathrm{~m})$ and elevation differences $(\sim 8 \mathrm{~m})$ in lowlying areas near the coastal line of Padang. Consequently, it is highly recommended to use an accurate local elevation dataset merged for tsunami inundation modeling and, hence, the DEM5 dataset is adopted in this study as land data.

\subsection{Vulnerability assessment of tsunami evacuation shelters to ground shaking and tsunami}

Prior to developing tsunami evacuation plans, structural vulnerability of TESs in Padang needs to be evaluated by con- sidering both ground shaking and tsunami hazards. Suitable seismic and tsunami fragility models are used to assess the vulnerability of the TESs by determining the probability that a building could sustain a certain damage state for a given earthquake scenario. Since the ground shaking affects the TESs before the tsunami, the seismic vulnerability assessment of TESs is carried out first, followed by the tsunami vulnerability assessment. In this study, the combined effects of earthquake shaking and tsunami are not taken into account, because such multi-hazard fragility models are not available 
(a)

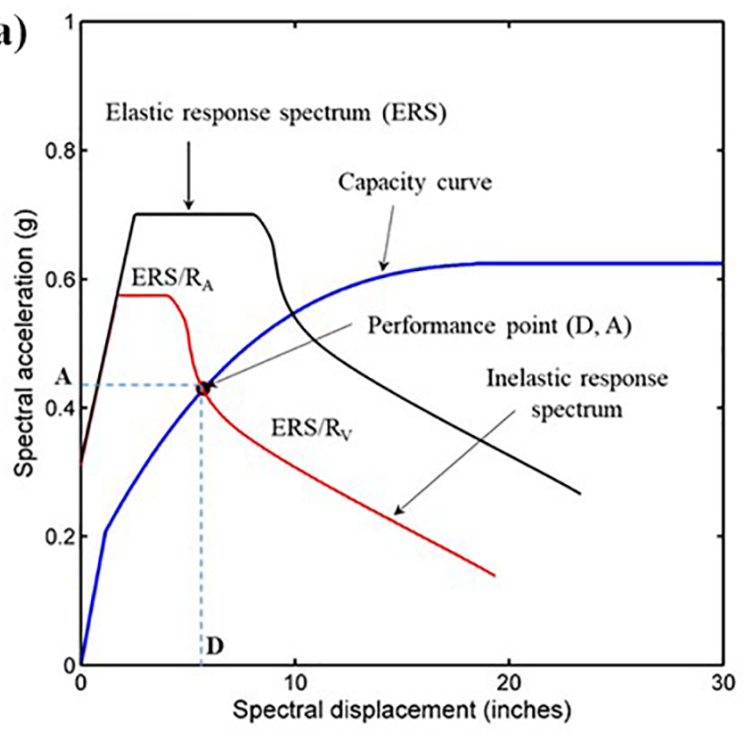

(b)

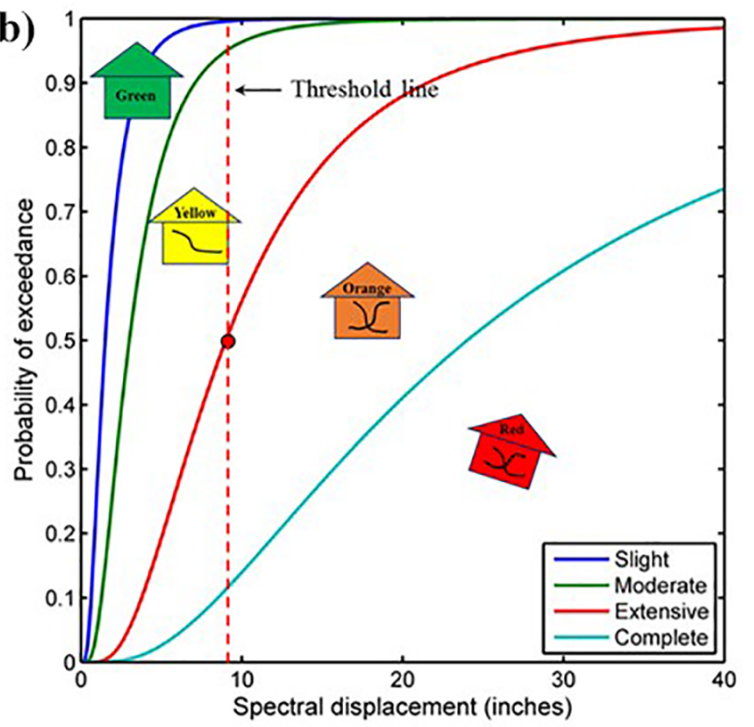

(c)

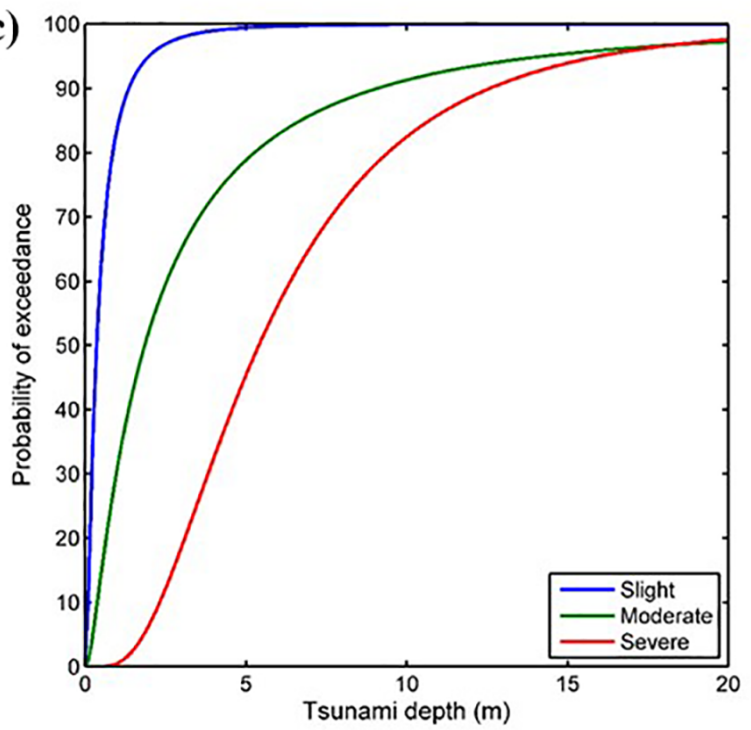

Figure 6. (a) Capacity spectrum method. (b) HAZUS seismic fragility curves. (c) Tsunami fragility curves developed by Suppasri et al. (2011).

for TESs in Padang. Detailed procedures for the earthquaketsunami vulnerability assessments of TESs are presented in the following sections.

\subsubsection{Earthquake simulation}

Seismic intensity measures for a given earthquake scenario at a TES can be effectively estimated using ground motion prediction equations (e.g., www.gmpe.org.uk). Because the capacity spectrum method (CSM) together with seismic fragility models is used for seismic vulnerability assessment (Sect. 2.2.2), elastic spectral accelerations (Sa) over a range of vibration periods need to be simulated for various earthquake scenarios from the Mentawai-Sunda region. In this study, among existing ground motion models, a relationship by Abrahamson et al. (2016) is adopted because it is developed and validated based on extensive global subduction ground motion databases (including ground motion data from the 2010 Maule Chile and 2011 Tōhoku earthquakes) and is applicable to megathrust interface subduction earthquakes in Sumatra, Indonesia. 

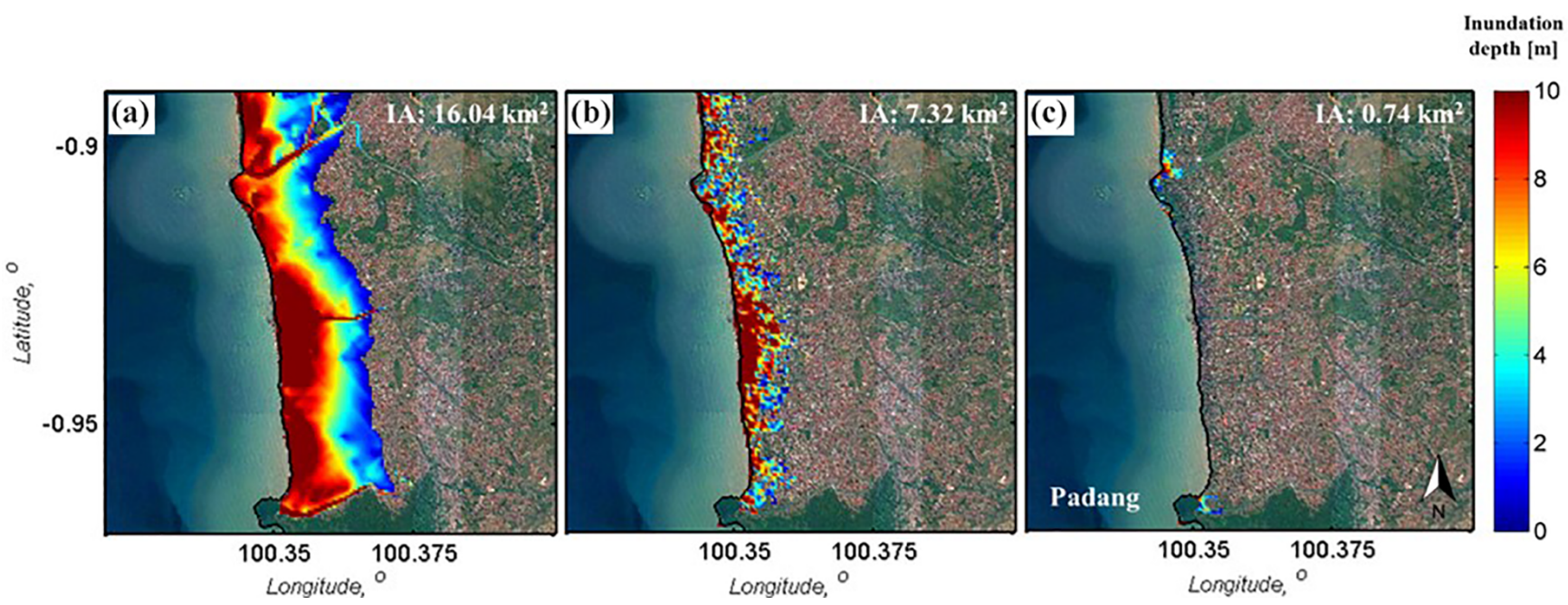

Figure 7. Inundation areas in Padang for (a) DEM5 and (b) SRTM1. (c) GDEM2 (IA is total inundation areas).

The formula to model ground motion intensities due to interface subduction earthquakes is given by

$$
\begin{aligned}
\ln \left(S_{a}\right)= & \theta_{1}+\theta_{4} \cdot \Delta C_{1}+\left[\theta_{2}+\theta_{3} \cdot\left(M_{\mathrm{W}}-7.8\right)\right] \\
& \cdot \ln \left\{R+C_{4} \cdot \exp \left[\theta_{9} \cdot\left(M_{\mathrm{w}}-6\right)\right]\right\}+\theta_{6} \cdot R \\
& +f_{\mathrm{MAG}}\left(M_{\mathrm{W}}\right)+f_{\mathrm{FABA}}(R) \\
& +f_{\mathrm{SITE}}\left(\mathrm{PGA}_{1000}, V_{\mathrm{S} 30}\right)+\sigma \cdot \varepsilon,
\end{aligned}
$$

where $\ln$ is the natural logarithm, $M_{\mathrm{W}}$ is the moment magnitude, $R(\mathrm{~km})$ is the closest distance to the rupture plane, $V_{\mathrm{S} 30}\left(\mathrm{~ms}^{-1}\right)$ is the average shear wave velocity in the uppermost $30 \mathrm{~m}$ of surface soil, $\mathrm{PGA}_{1000}$ is the median peak ground acceleration (PGA) value corresponding to $V_{\mathrm{S} 30}=$ $1000 \mathrm{~ms}^{-1}, \sigma$ is the total SD, and $\varepsilon$ is the Gaussian error term represented by zero mean and unit SD. The magnitude function is given by

$f_{\mathrm{MAG}}(M)=$

$\left\{\theta_{4} \cdot\left[M_{\mathrm{W}}-\left(7.8+\Delta C_{1}\right)\right]+\theta_{13} \cdot\left(10-M_{\mathrm{W}}\right)^{2} \quad\right.$ for $M_{\mathrm{W}} \leq 7.8+\Delta C_{1}$,

$\theta_{5} \cdot\left[M_{\mathrm{W}}-\left(7.8+\Delta C_{1}\right)\right]+\theta_{13} \cdot\left(10-M_{\mathrm{W}}\right)^{2} \quad$ for $M_{\mathrm{W}}>7.8+\Delta C_{1}$,

where $\Delta C_{1}$ captures the epistemic uncertainty related to the break in magnitude scaling. $f_{\mathrm{FABA}}(R)$ is the forearc or backarc term, which is equal to 0 for forearc or unknown site and 1 for backarc. Because Padang is in the forearc region of the Sumtara subduction zone, $f_{\mathrm{FABA}}(R)$ is set to 0 . Moreover, the site response scaling term is given by

$$
\begin{aligned}
f_{\mathrm{SITE}} & =\theta_{12} \cdot \ln \left(\frac{V_{\mathrm{S} 30}}{V_{\operatorname{lin}}}\right)-b \cdot \ln \left(\mathrm{PGA}_{1000}+c\right) \\
& +b \cdot \ln \left[\mathrm{PGA}_{1000}+c \cdot\left(\frac{V_{\mathrm{S} 30}}{V_{\mathrm{lin}}}\right)^{n}\right] \quad \text { for } V_{\mathrm{S} 30}<V_{\text {lin }} \\
& f_{\mathrm{SITE}}=\theta_{12} \cdot \ln \left(\frac{V_{\mathrm{S} 30}}{V_{\mathrm{lin}}}\right)+b \cdot n \cdot \ln \left(\frac{V_{\mathrm{S} 30}}{V_{\text {lin }}}\right) \quad \text { for } V_{\mathrm{S} 30} \geq V_{\mathrm{lin}} .
\end{aligned}
$$

All model coefficients included in Eqs. (6-8) can be found in Abrahamson et al. (2016).
To simulate ground motion intensities using the Abrahamson et al. model, three parameters are needed as inputs: magnitude, rupture distance, and average shear wave velocity for the considered site. For the TES assessment, only the worst magnitude earthquake scenario is considered $\left(M_{\mathrm{W}} 9.0\right)$, whilst the rupture distance is determined based on the closest distance between the location of interest and the rupture fault plane. Since the locations of TESs are relatively close one another (the maximum distance among the TESs is less than $3 \mathrm{~km}$ ) and this is significantly smaller than the distance between Padang and the earthquake source region, seismic vulnerability assessment is conducted for a single representative site in Padang. Subsequently, the shortest and longest source-to-site distances are calculated as $55 \mathrm{~km}$ and $\sim 100 \mathrm{~km}$, respectively, among the 100 earthquake scenarios. Moreover, $V_{\mathrm{S} 30}$ values in coastal areas of Padang range from 200 to $400 \mathrm{~m} \mathrm{~s}^{-1}$ (Putra et al., 2014) and, hence, $V_{\mathrm{S} 30}$ of $300 \mathrm{~m} \mathrm{~s}^{-1}$ is used in this study. Finally, to include the uncertainty of the prediction equation for multiple spectral acceleration ordinates, a multivariate lognormal distribution is adopted. The median values of spectral accelerations at different vibration periods (at a site of interest) are evaluated using the ground motion model with the three parameters, whereas their covariance matrix of the prediction error terms (i.e., $\sigma \varepsilon$ ) are based on inter-period correlation of ground motion parameters $\rho\left(T_{1} T_{2}\right)$ (see Baker and Cornell, 2006). The correlation coefficient matrix has diagonal elements equal to 1 and off-diagonal elements equal to the correlation coefficient $\rho\left(T_{1} T_{2}\right)$ and is calculated based on the following equation (Goda and Atkinson, 2009):

$$
\begin{aligned}
\rho\left(T_{1}, T_{2}\right)= & \frac{1}{3}\left(1-\cos \left\{\frac{\pi}{2}-\left[\theta_{1}+\theta_{2} I_{T_{\min <0.25}}\right.\right.\right. \\
& \left.\left.\left.\times\left(\frac{T_{\min }}{T_{\max }}\right)^{\theta_{3}} \log _{10}\left(\frac{T_{\min }}{0.25}\right)\right] \log _{10}\left(\frac{T_{\max }}{T_{\min }}\right)\right\}\right)
\end{aligned}
$$




$$
+\frac{1}{3}\left\{1+\cos \left[-1.5 \log _{10}\left(\frac{T_{\max }}{T_{\min }}\right)\right]\right\},
$$

where $\theta_{1}, \theta_{2}$, and $\theta_{3}$ are the model parameters $\left(\theta_{1}=1.374\right.$, $\theta_{2}=5.586$, and $\left.\theta_{3}=0.728\right) ; T_{\max }$ and $T_{\min }$ are the maximum and the minimum value of $T_{1}$ and $T_{2}$, respectively; and $I_{T_{\min <0.25}}$ is the indicator function that equals 1 if $T_{\min }<$ $0.25 \mathrm{~s}$ and equals 0 otherwise. Equation (9) was developed based on subduction earthquake records from Japan; thus, it is considered to be applicable to subduction earthquakes in Sumatra.

\subsubsection{Seismic vulnerability assessment}

The seismic vulnerability of TESs can be assessed using seismic fragility models. The fragility models relate the probability that a building's damage state exceeds a particular threshold for a ground motion parameter, such as PGA and Sa (Rossetto and Elnashai, 2003). In general, the seismic damage states (DS) can be categorized as slight (DS1), moderate (DS2), extensive (DS3), and complete (DS4) (see Table 3). Typically, for DS1, fine cracks in plaster partitions and infills to hairline cracking in beams and columns near joints $(<1 \mathrm{~mm})$ are found. For DS2, cracking occurs in most of the beams and columns along with larger flexural cracks and concrete spalling. For DS3, some elements of the building may reach their ultimate capacity revealed as large flexural cracking, concrete spalling, and rebar buckling (Rosetto and Elnashai, 2003; see Table 3). The damage states for tsunami differ from those for ground shaking. Subsequently, in this study, the seismic fragility curves developed for and implemented in HAZUS (2003) are adopted to assess the vulnerability of TESs in Padang for the following reasons:

1. The TESs are designed and constructed according to the new Indonesian Earthquake Resistance Building Code (SNI-1726: 2002 and 2012), which adopted the US seismic design documents, i.e., FEMA P750 (2009), regarding seismic design provisions for new building and other structures, and ASCE/SEI 7-05 for the minimum design load criterion (ASCE, 2006; SNI-1726: 2012; Kurniawan et al., 2014; Wijayanti et al., 2015; Aulia, 2016; Sengara et al., 2016).

2. HAZUS is a well-established earthquake loss estimation framework and has been implemented in several earthquake-prone countries for seismic risk assessment purposes, e.g., Haiti, Puerto Rico, France, Romania, Austria, and Indonesia (Kulmesh, 2010; Peterson and Small, 2012; Wijayanti et al., 2015; Sengara et al., 2016).

In HAZUS, building performance under seismic actions is evaluated based on the CSM. The CSM compares the structural capacity in terms of capacity curve with the seismic demand on a structure that account for post-yielding inelastic behavior of the structural system. The nonlinear inelastic behavior of the structural system is taken into account by applying the effective reduction factor to the elastic response spectrum (ERS) of the considered earthquake scenario (Freeman, 2004; Kim et al., 2005; Monteiro et al., 2014). The performance point, which is the expected seismic response of a structural system for a given earthquake scenario, can be obtained graphically as an intersection point of the capacity and demand curves. Figure 6a illustrates the procedure for developing an inelastic response (demand) spectrum from the elastic response (input) spectrum in HAZUS. First, the acceleration response spectrum is generated from the earthquake simulation (see Sect. 2.2.1) and is further converted into the acceleration-displacement response spectrum (ADRS). In the CSM, the ADRS is defined as the ERS. Second, the inelastic demand spectrum is calculated by dividing the ERS by the reduction factors (i.e., $R_{\mathrm{A}}$ at periods of constant acceleration and $R_{\mathrm{V}}$ at periods of constant velocity). Note that the reduction factors in HAZUS are equal to the reciprocal of $S R_{\mathrm{A}}$ and $S R_{\mathrm{V}}$ in ATC-40 (ATC, 1996). For essential and average buildings (type B), the $S R_{\mathrm{A}}$ and $S R_{\mathrm{V}}$ should be less than 2.27 and 1.79, respectively (ATC, 1996). In contrast, the TESs may be classified as type B based on the ATC- 40 system and, hence, $R_{\mathrm{A}}$ and $R_{\mathrm{V}}$ should be less than 2.27 and 1.79 , respectively. In this study, both $R_{\mathrm{A}}$ and $R_{\mathrm{V}}$ are set to 1.5 (Lin and Chang, 2003; Casarotti et al., 2009; Monteiro et al., 2014). Third, the capacity curve taken from HAZUS is overlaid to compare with the inelastic response spectrum (see blue line in Fig. 6a). The capacity curve in HAZUS is defined based on two parameters: yield and ultimate strengths characterizing the nonlinear (pushover) behavior. The building-type classifications in HAZUS are based on the building material (e.g., wood, reinforced concrete, steel) and height. Following the HAZUS classification, the TES in Padang is categorized as reinforced concrete moment resistant frames (RC-MRF) with different building heights. TESs 13 and 16 are high-rise RC-MRF $(\mathrm{C} 1 \mathrm{H})$, whereas the rest of the TESs are mid-rise RC-MRF (C1M). Moreover, in HAZUS, four seismic design code classifications (Pre-Code, Low-Code, Moderate-Code, and High-Code) are defined corresponding to the seismic zone. In terms of seismic design code classification, HighCode is applicable to TESs in Padang, because Padang is located in the high seismic zone and TESs have been designed and constructed to higher standards/quality than other normal buildings (Kurniawan et al., 2014; Aulia, 2016). In the following, the seismic vulnerability assessment of TESs is carried out by focusing upon C1M because the $\mathrm{C} 1 \mathrm{H}$ type is typically stronger than $\mathrm{C} 1 \mathrm{M}$ in terms of capacity curve (i.e., for the same shaking intensity, $\mathrm{CH} 1$ buildings are expected to perform better than CM1).

Finally, seismic fragility curves implemented in HAZUS are used to define the damage functions of the building; typically, the fragility functions are defined using the lognormal distribution. Four damage states - slight, moderate, extensive, and complete - are defined in HAZUS (see Table 3 
and Fig. $6 \mathrm{~b}$ for the descriptions). Subsequently, to determine whether a TES can be used for post-earthquake tsunami evacuation purposes (not for shelters), the building is categorized into safe and unsafe by referring to existing tagging criteria (FEMA 356, 2000; HAZUS, 2003; Bazzurro et al., 2006) including the following (see Fig. 6b)

- Green tag: the building may have experienced onset damage but is safe for immediate occupancy. The noneto-slight damage state is applicable.

- Yellow tag: re-occupancy of the building is restricted and limited access only is allowed. Moderate-toextensive damage state corresponds to this case.

- Red tag: the building is unsafe and no access is granted and will be completely damaged or collapsed.

Based on the above tagging criteria, the tsunami evacuation building may be judged as unsafe for evacuation if the probability of extensive and complete damage states is over $50 \%$. This assumption gives a 50-50 chance that the building may experience above or below extensive damage (Bazzurro et al., 2006). Moreover, the $50 \%$ probability of extensive or severe damage is typically identified as the threshold value of a yellow tag in HAZUS that is adopted in this study (see Fig. 6b) and, hence, may be regarded as the limit state to define the accessibility of buildings for emergency evacuation during the tsunami inundation.

\subsubsection{Tsunami vulnerability assessment and TES capacity estimation}

Once the TES is judged to be accessible for tsunami evacuation through the seismic vulnerability assessment, a tsunami vulnerability assessment is then carried out. The tsunami fragility models evaluate the probability of experiencing certain damage states for a building due to tsunami. The tsunami damage criteria for buildings are defined by the MLITT (2013) and are shown in Table 4.

In current literature, most tsunami fragility models have been developed using post-tsunami survey data, remote sensing data, and numerical modeling (e.g., Dias et al., 2009; Koshimura et al., 2009; Suppasri et al., 2011). In this study, the model by Suppasri et al. (2011) is adopted for the following reasons. It was developed through extensive remote sensing and tsunami survey data (i.e., $\sim 5000$ points) in Banda Aceh and Thailand for the 2004 Aceh-Andaman tsunami and is the most recent model among existing tsunami fragility models that are applicable to Sumatra, Indonesia. These features are important because current situations of tsunami mitigation measures in Padang resemble those in Banda Aceh and Thailand more closely than situations in other regions. The Suppasri et al. model considers three damage states for tsunami damage (see Fig. 6c) and consists of three fragility curves for reinforced concrete building for slight (DST1), moderate (DST2), and major/severe damage state (DST3).
Using the calculated probability exceedance of each damage state, the TES is considered to be unsafe when the exceedance probability of severe damage is above $50 \%$ (the major tsunami damage is assumed to be similar to the extensive damage in seismic damage state criteria).

Subsequently, when the seismic and tsunami vulnerability assessment confirmed that the TES is operational for evacuation, the TES capacity for accommodation is calculated. This is evaluated by calculating the TES capacity (TESC):

$\mathrm{TESC}=(\mathrm{EAF} \times \mathrm{NF}) / \mathrm{SpP}$,

where EAF is the existing evacuation area at each floor and $\mathrm{NF}$ is the total number of floors excluding inundated floor (Budiarjo, 2006; Widyaningrum, 2009; Dewi, 2012). Several assumptions are made to calculate the TES building capacity, which are the following:

1. Floors of the TES buildings are categorized into two floor types: unsafe floor and evacuation floor. The unsafe floor is the floor that is inundated by the tsunami, whilst the evacuation floor is the floor for evacuation areas. Moreover, the inundated floor is considered to be unsafe for evacuation and thus is excluded from building capacity estimation during the tsunamigenic event.

2. Space needed per person $(\mathrm{SpP})$ at the evacuation areas in each TES building is $1 \mathrm{~m}^{2}$ determined based on $0.8 \mathrm{~m}^{2}$ for stay and $0.2 \mathrm{~m}^{2}$ for circulation (BAPPENAS, 2005; Budiarjo, 2006; Widyaningrum, 2009; Dewi, 2012). This value is similar to that recommended by (FEMA P-646, 2012), i.e., $0.93 \mathrm{~m}^{2}$ per person.

3. Existing evacuation area in each floor of the TES building is assumed to be equal for all floors because only total evacuation area data for the whole building are available.

\subsubsection{Evacuation time maps}

Next, horizontal and vertical tsunami evacuation time maps are developed based on the total evacuation time (TET), which is calculated by summing initial reaction time (IRT) and evacuation time (ET).

$$
\begin{aligned}
& \mathrm{TET}=\mathrm{IRT}+\mathrm{ET} \\
& \mathrm{IRT}=\mathrm{DT}+\mathrm{NT}+\mathrm{RT}
\end{aligned}
$$

The IRT is the actual response time for the community to start the evacuation, whilst the evacuation time is the time needed for the community to evacuate to the safe areas. In principle, three components are considered to calculate the IRT during the tsunamigenic event including institutional decision time (DT), institutional notification time (NT), and reaction time of the community (RT), as presented in Eq. 12). The institutional times (DT and NT) are determined by the 

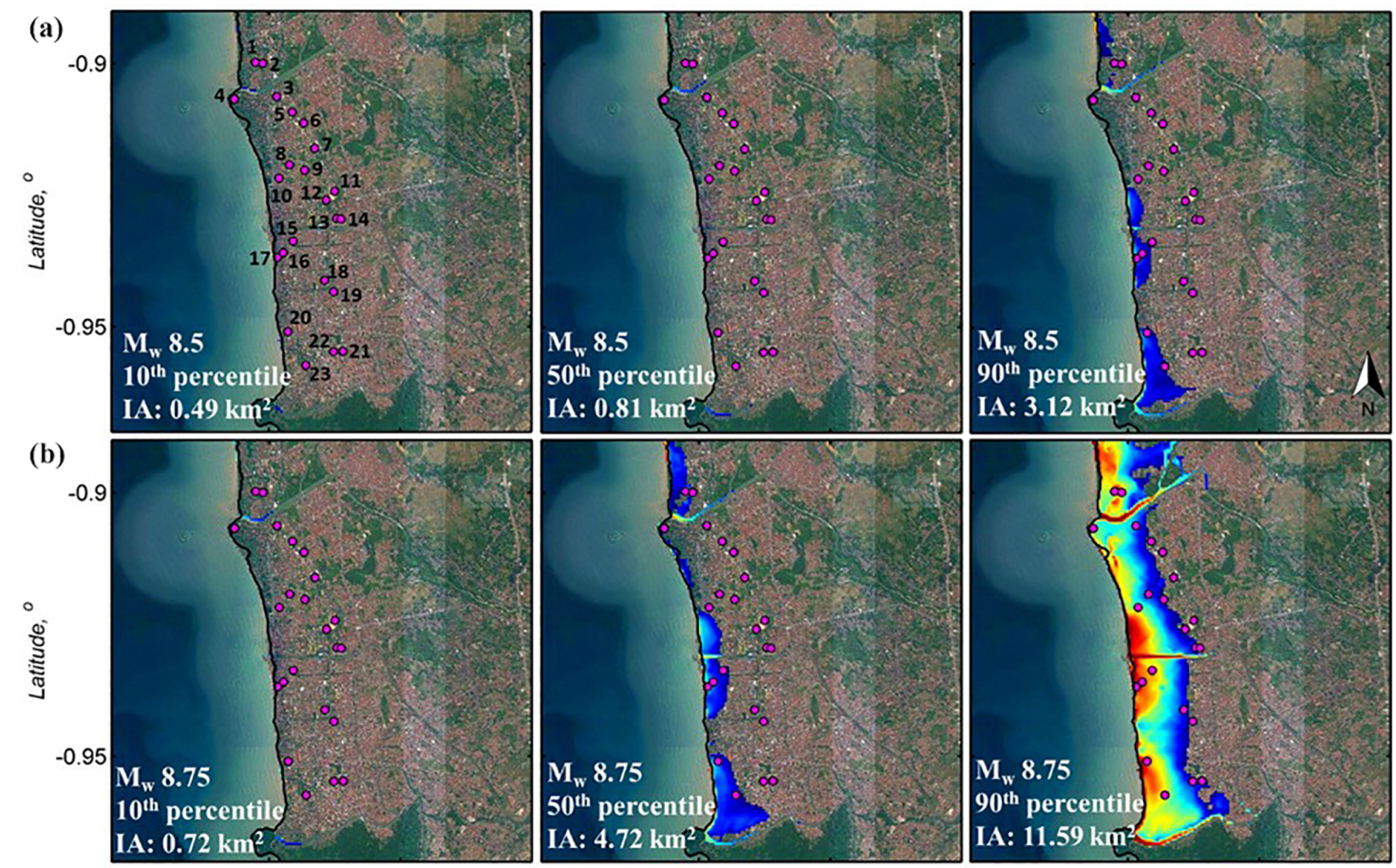

Tsunami
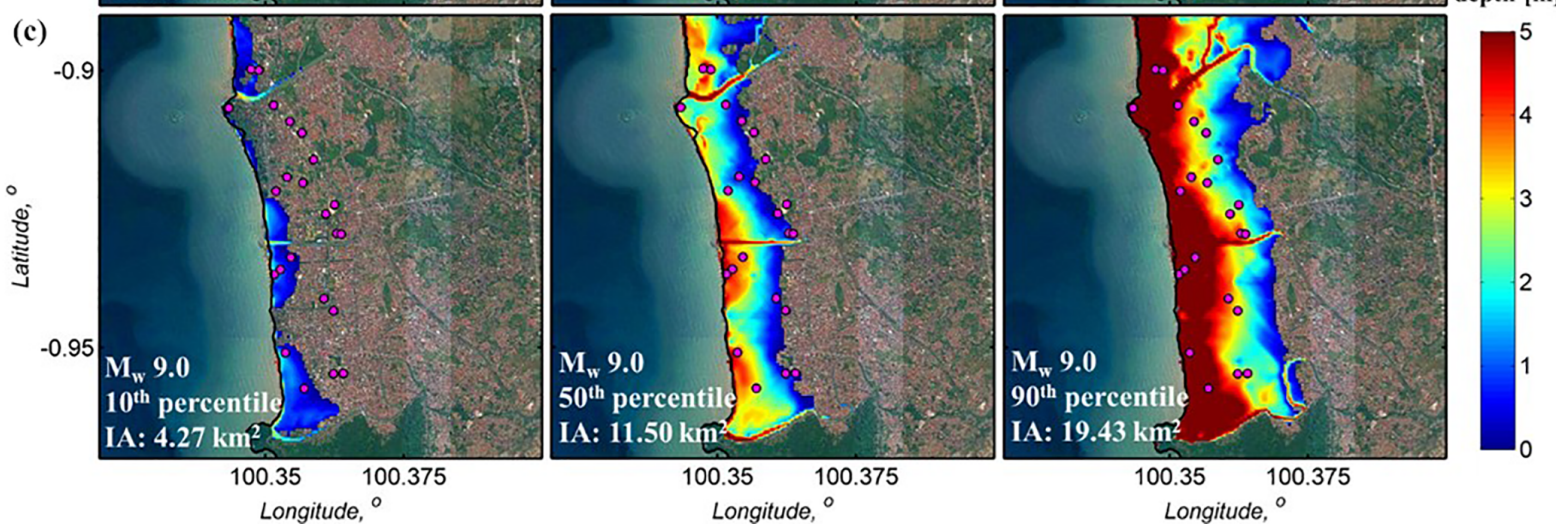

Figure 8. Inundation depth maps in Padang: (a) $M_{\mathrm{W}} 8.5$ scenario, (b) $M_{\mathrm{W}} 8.75$ scenario, and (c) $M_{\mathrm{W}} 9.0$ scenario (IA is inundation area).

related government institution, which has the authority to issue hazard warnings (Charnkol and Tanaboriboon, 2006; Post et al., 2009). In Indonesia, the official institution to release a tsunami warning is the Indonesia Tsunami Early Warning System of Indonesian Agency for Meteorology, Climatology and Geophysics (INA-TEWS of BMKG). The INA-TEWS normally needs $5 \mathrm{~min}$ to issue tsunami warning (Widyaningrum, 2009; Dewi, 2012). In addition, the institutional notification time is assumed to be $3 \mathrm{~min}$, whilst the RT of the community is 7-10 min (Charnkol and Tanaboriboon, 2006; Post et al., 2009). In this study, the IRT used is $15 \mathrm{~min}$ by adopting the community reaction time of $7 \mathrm{~min}$. Moreover, a suitable range of the travel speed is found to be 0.91 to $3.83 \mathrm{~m} \mathrm{~s}^{-1}$, depending on the traveling method (by foot or vehicle) and the evacuees' ages (Wood et al., 2012). In this study, the evacuation time is calculated based on the slowest travel speed $\left(0.91 \mathrm{~ms}^{-1}\right)$ to capture the worst scenario. The evacuation time is estimated crudely by excluding roads leading to the safe places and other essential parameters (e.g., population density and age classification). Although the approximate method is not able to capture the realistic situation of evacuation accurately, it is considered to be useful for emergency managers (e.g., regional disaster management stakeholders) to develop a city-wide tsunami evacuation plan.

Finally, the integrated evacuation time maps are developed by combining horizontal and vertical evacuation time maps. The integrated evacuation time maps are calculated by taking a minimum evacuation time between evacuations horizontally and vertically. These maps are essential for the rescue teams to consider both evacuation options and subsequently may reduce the casualties during the tsunami event. 

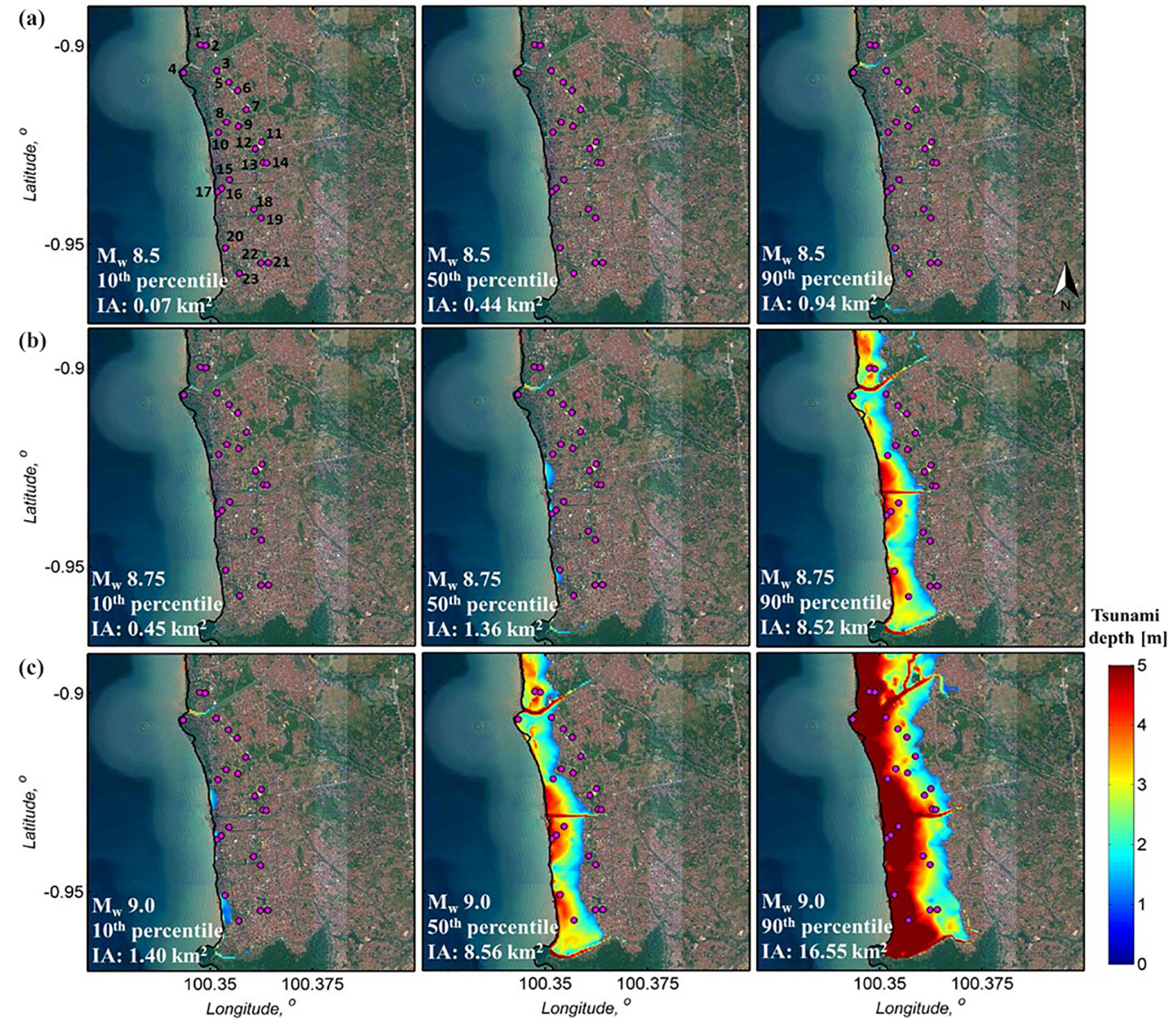

Figure 9. Inundation areas above $1 \mathrm{~m}$ depth in Padang: (a) $M_{\mathrm{W}} 8.5$ scenario, (b) $M_{\mathrm{W}} 8.75$ scenario, and (c) $M_{\mathrm{W}} 9.0$ scenario (IA is inundation area).

\section{Results}

The main results that are discussed in this section focus on the tsunami hazard level in Padang produced from all earthquake scenarios $M_{\mathrm{w}} 8.5,8.75$, and 9.0 (Sect. 3.1); a vulnerability assessment of TESs considering impacts of seismic and tsunami in Padang using the $M_{\mathrm{w}} 9.0$ scenario (Sect. 3.2); and horizontal, vertical, and integrated evacuation time maps during the tsunamigenic event using the $M_{\mathrm{w}} 9.0$ scenario (Sect. 3.3).

\subsection{Tsunami hazard level in Padang}

The tsunami hazard level in Padang is investigated by assessing the tsunami height and depth produced from the stochastic tsunami simulations for three magnitude scenarios. The height presented in this study is the height of water flow above the mean sea level, whilst the depth refers to the water flow height above the ground. Firstly, the maximum inundation depth maps for all scenarios along with the maximum inundation depth maps for the areas above $1 \mathrm{~m}$ depth are presented and discussed. Secondly, the inundation heights along the coastal line and three main rivers in Padang, i.e., (1) Kuranji river, (2) Banda Bakali river, and (3) Arau river, are discussed (see Fig. 3a). The inundation footprints along the rivers are concerned because the tsunami flow may penetrate far inland through the rivers, as observed in the 2011 Tōhoku event (Mori et al., 2011; Tanaka et al., 2014).

The maximum inundation depth maps in Padang are presented in Fig. 8, whilst the total inundation areas for the depth above $1 \mathrm{~m}$ are shown in Fig. 9. Three maps in each magnitude scenario are for the 10th percentile (left panel), the 50th percentile (central panel), and the 90th percentile (right panel). 

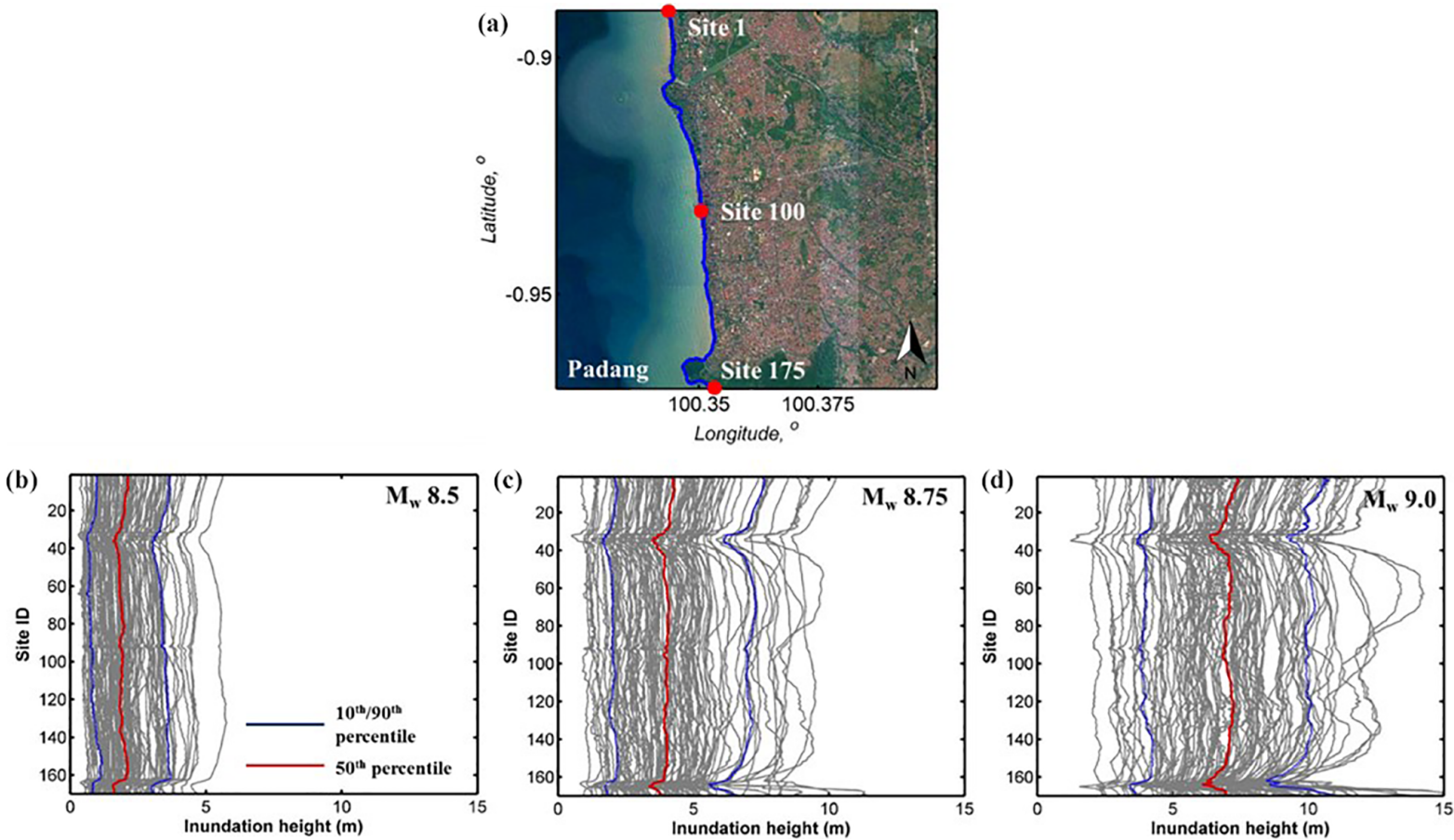

Figure 10. (a) Site location. (b) Maximum tsunami inundation height in the coastal line of Padang for the $M_{\mathrm{W}} 8.5$ scenario. (c) Maximum tsunami inundation height in the coastal line of Padang for the $M_{\mathrm{W}} 8.75$ scenario. (d) Maximum tsunami inundation height in the coastal line of Padang for the $M_{\mathrm{W}} 9.0$ scenario.
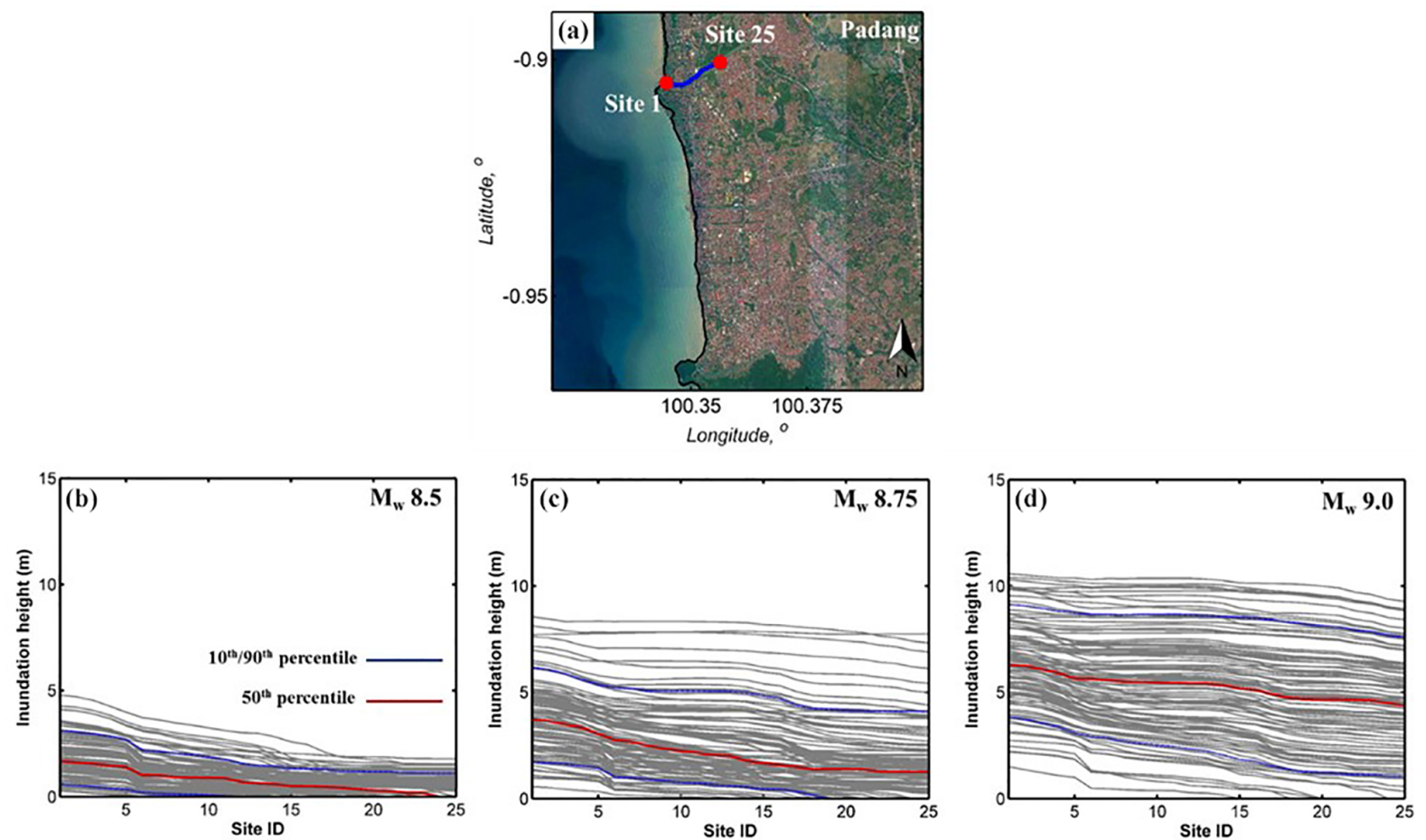

Figure 11. (a) Site location. (b) Maximum tsunami inundation height in the first river of Padang for the $M_{\mathrm{W}} 8.5$ scenario. (c) Maximum tsunami inundation height in the first river of Padang for the $M_{\mathrm{W}} 8.75$ scenario. (d) Maximum tsunami inundation height in the first river of Padang for the $M_{\mathrm{W}} 9.0$ scenario. 
Figure $8 \mathrm{a}$ shows that the tsunami impacts for the case of $M_{\mathrm{w}} 8.5$ are insignificant in Padang. The total inundated areas exhibited in the 90th percentile map of the $M_{\mathrm{w}} 8.5$ scenario are relatively minor (only $3.12 \mathrm{~km}^{2}$ ). Those inundated areas are concentrated near the coastal line of Padang with the total inundation areas above $1 \mathrm{~m}$ depth is only $0.94 \mathrm{~km}^{2}$ (see the right panel of Fig. 9a). These results are much smaller than the maximum tsunami inundation areas for the same magnitude scenario $\left(M_{\mathrm{w}} 8.5\right)$ produced by the GITEWS (Goseberg and Schulrmann, 2009; Taubenbock et al., 2009; Schlurmann et al., 2010). This is due to the use of deterministic source scenarios in which large earthquake slips are placed very close to Padang (less than $20 \mathrm{~km}$ ). Consequently, the considered earthquake scenarios used in the GITEWS project may overpredict the tsunami inundation areas. In addition, the inundation areas increase significantly from the $M_{\mathrm{w}} 8.5$ scenario to the $M_{\mathrm{w}} 8.75$ scenario as shown in the 90 th percentile maps. The maximum total inundation areas for the $M_{\mathrm{w}} 8.75$ case are about four times larger than the $M_{\mathrm{w}} 8.5$ scenario (increasing from 3.12 to $11.59 \mathrm{~km}^{2}$ ). The inundation areas above $1 \mathrm{~m}$ depth for the 90th percentile of the $M_{\mathrm{w}} 8.75$ case also increase drastically to $8.52 \mathrm{~km}^{2}$ as presented in the right panel of Fig. 9b.

Moreover, the tsunami effects are found to be much more significant for the $M_{\mathrm{w}} 9.0$ scenario. The total inundation areas above $1 \mathrm{~m}$ depth reach $16.55 \mathrm{~km}^{2}$ at the 90th percentile. The evacuation from the inundated areas might be very difficult in such a situation. However, in general, the maximum tsunami-affected areas produced from the stochastic tsunami simulations are larger than the results from the GITEWS project, which are used to build the current evacuation plan in Padang (Taubenbock et al., 2009; Schlurmann et al., 2010). The existing tsunami evacuation plan may oversimplify the future tsunamigenic event and, therefore, the improvements of these maps are highly desirable to capture the worst scenarios that may occur in the future.

To capture the variability of inundation extent in Padang, Figs. 10-13 show the inundation height profiles along the coastal line and three rivers in Padang. The length of the $\mathrm{Ku}-$ ranji, Banda Bakali, and Arau rivers from their river mouths are $1.4,1.7$, and $2.45 \mathrm{~km}$, respectively. In general, high variability of inundation heights is found along the coastal line of Padang (Fig. 10). The 10th rank from the three magnitude scenarios shows that the tsunami wave heights along the coastal line range from $0 \mathrm{~m}$ (for the $M_{\mathrm{w}} 8.5$ scenario) to $3 \mathrm{~m}$ (for the $M_{\mathrm{W}} 9.0$ scenario). By contrast, for the 90th rank of the $M_{\mathrm{w}} 9.0$ scenario, the maximum tsunami height reaches $10 \mathrm{~m}$. Moreover, the inundation heights along the rivers (see Figs. 11-13) also show high variability of the wave height, ranging between 0 and $10 \mathrm{~m}$. The 10th and 50th percentiles of inundation heights for the $M_{\mathrm{w}} 8.5$ and $M_{\mathrm{w}} 8.75$ scenarios tend to decrease to zero as the locations go further inland. However, the tsunami inundation heights remain almost constant along the rivers for the $M_{\mathrm{w}} 9.0$ case, as presented for the 50th and 90th ranks. This highlights that the tsunami waves
Table 3. Description of seismic damage state (HAZUS, 2003; Rosetto and Elnashai, 2003).

\begin{tabular}{lll}
\hline \multicolumn{2}{l}{ Damage state } & Description \\
\hline DS1 & Slight & $\begin{array}{l}\text { Ranging from minimal damage of the } \\
\text { structural and nonstructural compo- } \\
\text { nents to minor nonstructural and struc- } \\
\text { tural damage. }\end{array}$ \\
\hline DS2 & Moderate & $\begin{array}{l}\text { Moderate nonstructural and structural } \\
\text { damage. }\end{array}$ \\
\hline DS3 & Extensive & $\begin{array}{l}\text { Extensive structural and nonstructural } \\
\text { damage. Localized life-threatening sit- } \\
\text { uations are common. }\end{array}$ \\
\hline DS4 & $\begin{array}{l}\text { Complete } \\
\text { (collapse) }\end{array}$ & $\begin{array}{l}\text { Building is fully destroyed, with signifi- } \\
\text { cant portions of the building having col- } \\
\text { lapsed. }\end{array}$ \\
\hline
\end{tabular}

can run up the rivers by more than $2 \mathrm{~km}$ from the coastal line and, hence, people who live along the rivers may be more affected. In addition, the inundation height profiles along the coastal line and the rivers in Padang show that the stochastic tsunami simulation method can capture the uncertainty of the inundation extent. Therefore, the implementation of the stochastic tsunami simulation method for predicting the future events is highly desirable for preparing more effective and robust mitigation plans.

\subsection{Vulnerability assessment of tsunami evacuation shelters}

Currently, in east and north of Padang, 23 TESs have been set up or designated by the National Agency for Disaster Management (BNPB) of Padang (see Table 2). However, their adequacy as emergency evacuation building was evaluated under the design scenarios only. Consequently, re-assessment of TESs in Padang is highly desirable by taking into account uncertainties associated with the tsunami hazards. This will provide residents and emergency/rescue teams with valuable information regarding the current tsunami risk exposure in Padang. In this section, the tsunami inundation depth variability at each TES building is firstly discussed. The vulnerability of each TES is then assessed and discussed by considering the worst seismic and tsunami scenarios $\left(M_{\mathrm{w}} 9.0\right)$.

First, the variability of tsunami inundation depth at each TES is shown in Fig. 14. The tsunami impacts to all TESs are insignificant in the case of $M_{\mathrm{w}} 8.5$ for all percentiles. The tsunami depths at the TES locations from 100 tsunami simulations are zero for the majority of the cases. The tsunami impacts start to increase for the $M_{\mathrm{w}} 8.75$ scenario. In this scenario, the variability of inundation depth at several TESs (e.g., shelters 16, 17, 20, and 23) ranges from $0 \mathrm{~m}$ to more than $5 \mathrm{~m}$. However, the 90th percentile values of tsunami depth for all TESs are still below $5 \mathrm{~m}$. Significant impacts are 

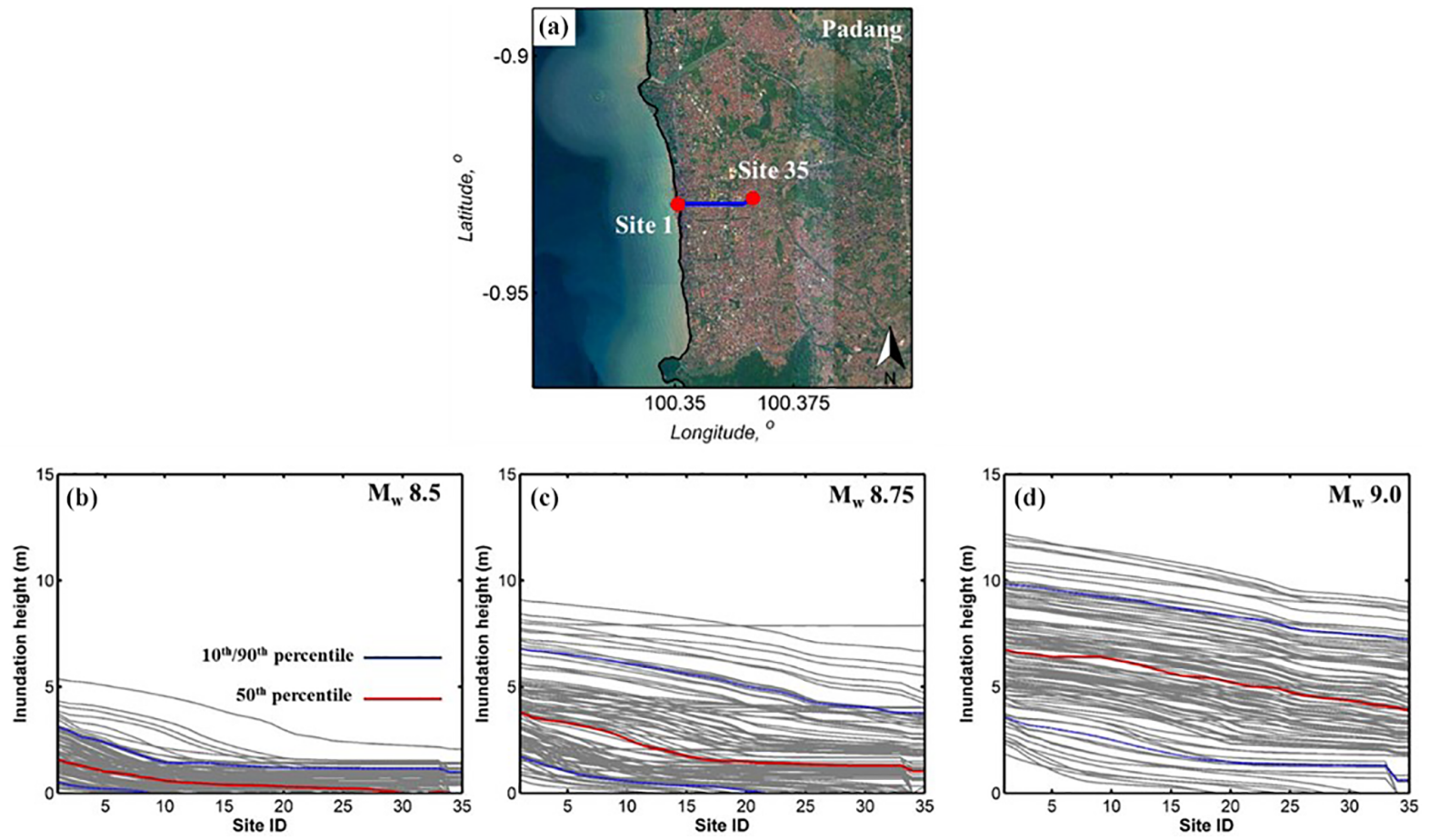

Figure 12. (a) Site location. (b) Maximum tsunami inundation height in the second river of Padang for the $M_{\mathrm{W}} 8.5$ scenario. (c) Maximum tsunami inundation height in the second river of Padang for the $M_{\mathrm{W}} 8.75$ scenario. (d) Maximum tsunami inundation height in the second river of Padang for the $M_{\mathrm{W}} 9.0$ scenario.
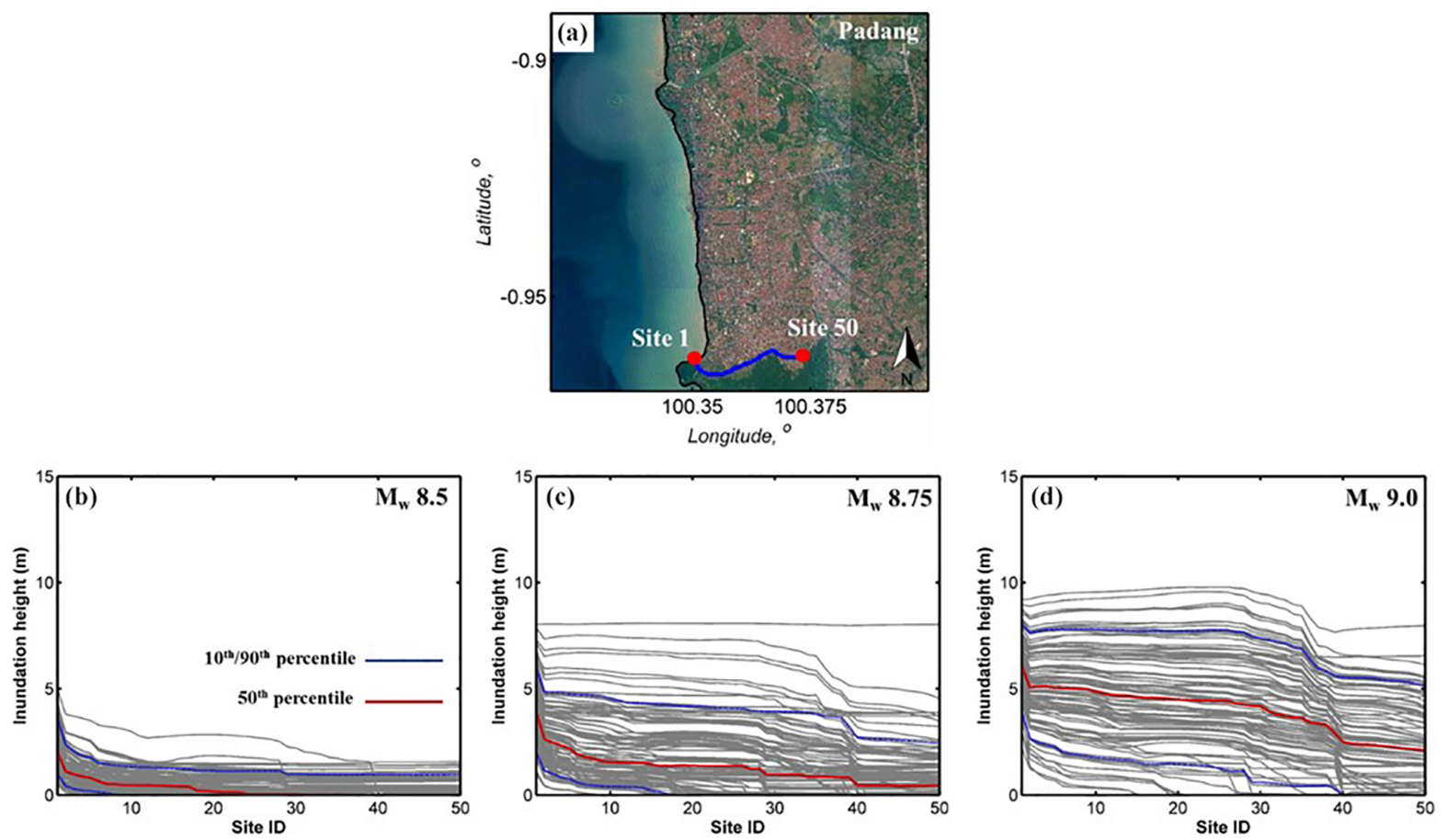

Figure 13. (a) Site location. (b) Maximum tsunami inundation height in the third river of Padang for the $M_{\mathrm{W}} 8.5$ scenario. (c) Maximum tsunami inundation height in the second river of Padang for the $M_{\mathrm{W}} 8.75$ scenario. (d) Maximum tsunami inundation height in the third river of Padang for the $M_{\mathrm{W}} 9.0$ scenario. 
Table 4. Damage state definitions for tsunami (Suppasri et al., 2014; Charvet et al., 2017).

\begin{tabular}{llll}
\hline Damage state & Description & Use \\
\hline DST0 & No damage & Water does not flow into the building & Immediate occupancy \\
\hline DST1 & Minor damage & Water enters below the ground floor & $\begin{array}{l}\text { Possible to use immediately af- } \\
\text { ter minor cleanup }\end{array}$ \\
\hline DST2 & Moderate damage & $\begin{array}{l}\text { Water inundates to less than } 1 \mathrm{~m} \text { above the } \\
\text { ground floor }\end{array}$ & $\begin{array}{l}\text { Possible to use immediately af- } \\
\text { ter moderate repairs }\end{array}$ \\
\hline DST3 & Major damage & $\begin{array}{l}\text { Water inundates to more than 1 m above the } \\
\text { ground floor (but below the ceiling }\end{array}$ & $\begin{array}{l}\text { Possible to use immediately af- } \\
\text { ter major repairs }\end{array}$ \\
\hline DST4 & Complete damage & $\begin{array}{l}\text { The building is inundated above the ground } \\
\text { floor level }\end{array}$ & Major repairmen is needed \\
\hline DST5 & Collapsed & Structural elements are significantly damage & Not repairable \\
\hline DST6 & Washed away & The building is completely washed away & Not repairable \\
\hline
\end{tabular}

Table 5. Assessment of tsunami evacuation shelters (TES) in Padang in terms of depth, tsunami arrival time, and number of tsunami destructive events.

\begin{tabular}{|c|c|c|c|c|c|c|}
\hline \multirow[t]{2}{*}{ No. } & \multirow{2}{*}{$\begin{array}{r}\text { TES } \\
\text { height } \\
(\mathrm{m})\end{array}$} & \multirow{2}{*}{$\begin{array}{r}\begin{array}{r}10 \text { th } \\
\text { percentile }\end{array} \\
\begin{array}{r}\text { Depth } \\
(\mathrm{m})\end{array}\end{array}$} & \multirow{2}{*}{$\begin{array}{r}\begin{array}{r}50 \text { th } \\
\text { percentile }\end{array} \\
\begin{array}{r}\text { Depth } \\
(\mathrm{m})\end{array}\end{array}$} & \multicolumn{2}{|c|}{ 90th percentile } & \multirow{2}{*}{$\begin{array}{r}\text { Percentage of } \\
\text { destructive } \\
\text { events }(\%)\end{array}$} \\
\hline & & & & $\begin{array}{r}\text { Depth } \\
(\mathrm{m})\end{array}$ & $\begin{array}{r}\text { Tsunami arrival } \\
\text { time (min) }\end{array}$ & \\
\hline 1 & 10 & 0 & 2.9 & 6 & 23 & 16 \\
\hline 2 & 20 & 0.5 & 3.9 & 7 & 24 & 25 \\
\hline 3 & 15 & 0 & 1.4 & 4.6 & 25 & 6 \\
\hline 4 & 15 & 0 & 2.6 & 5.7 & 19 & 11 \\
\hline 5 & 10 & 0 & 0.1 & 3.1 & 27 & 1 \\
\hline 6 & 20 & 0 & 0 & 2.5 & 30 & 1 \\
\hline 7 & 15 & 0 & 0 & 1.9 & 30 & 1 \\
\hline 8 & 10 & 0 & 0.8 & 3.6 & 24 & 5 \\
\hline 9 & 10 & 0 & 0.2 & 3 & 25 & 1 \\
\hline 10 & 10 & 0 & 2.1 & 5.1 & 21 & 8 \\
\hline 11 & 47 & 0 & 0 & 2.2 & 30 & 1 \\
\hline 12 & 15 & 0 & 0 & 2.8 & 28 & 1 \\
\hline 13 & 52 & 0 & 0.8 & 4 & 28 & 4 \\
\hline 14 & 15 & 0 & 0 & 3.1 & 30 & 1 \\
\hline 15 & 10 & 0.3 & 3.6 & 6.7 & 20 & 24 \\
\hline 16 & 30 & 1.2 & 4.3 & 7.5 & 17 & 30 \\
\hline 17 & 15 & 1.6 & 4.8 & 7.8 & 15 & 36 \\
\hline 18 & 20 & 0 & 0.5 & 3.8 & 27 & 1 \\
\hline 19 & 10 & 0 & 0 & 3 & 29 & 1 \\
\hline 20 & 22 & 1.3 & 4 & 6.8 & 17 & 25 \\
\hline 21 & 25 & 0 & 0.3 & 2.9 & 28 & 1 \\
\hline 22 & 10 & 0 & 0.5 & 3.1 & 27 & 1 \\
\hline 23 & 25 & 0.5 & 2.9 & 5.6 & 20 & 12 \\
\hline
\end{tabular}

shown from the variability of tsunami inundation depth for the $M_{\mathrm{w}} 9.0$ scenario. Three out of the 23 TESs, i.e., shelters 1,15 , and 22 , with the building height of $10 \mathrm{~m}$ may be significantly affected by the tsunami. The depth variability in those three buildings ranges from $0 \mathrm{~m}$ to nearly $10 \mathrm{~m}$ (see Fig. 14c). Additional information regarding the depth variability at the
TES locations is also presented in Fig. 15 developed from the $M_{\mathrm{w}} 9.0$ scenario. Eleven of the 23 TES locations (i.e., shelters 1, 2, 3, 4, 10, 13, 15, 16, 17, 20, and 23) are chosen to illustrate the depth variability and tsunami arrival time at the TES sites. These stations are located close to the coastal line and the rivers (see Fig. 3) and thus are majorly affected 
Table 6. TES building capacity during the tsunami event considering the $M_{\mathrm{W}} 9.0$ scenario.

\begin{tabular}{|c|c|c|c|c|c|c|c|c|c|c|c|c|c|}
\hline \multirow[b]{2}{*}{ No. } & \multirow[b]{2}{*}{$\begin{array}{r}\text { Building } \\
\text { height }\end{array}$} & \multirow[b]{2}{*}{$\begin{array}{l}\text { Total } \\
\text { floor }\end{array}$} & \multirow[b]{2}{*}{$\begin{array}{r}\text { Total } \\
\text { evacuation } \\
\text { area }\left(\mathrm{m}^{2}\right)\end{array}$} & \multirow[b]{2}{*}{$\begin{array}{l}\text { Evacuation } \\
\text { area in each } \\
\text { floor }\left(\mathrm{m}^{2}\right)\end{array}$} & \multicolumn{3}{|c|}{ 10th percentile } & \multicolumn{3}{|c|}{ 50th percentile } & \multicolumn{3}{|c|}{ 90th percentile } \\
\hline & & & & & $\begin{array}{r}\text { Inundation } \\
\text { depth }(\mathrm{m})\end{array}$ & $\begin{array}{r}\text { Number of } \\
\text { evacuation } \\
\text { floor }\end{array}$ & $\begin{array}{r}\text { Capacity } \\
\text { during } \\
\text { tsunami } \\
\text { (person) }\end{array}$ & $\begin{array}{r}\text { Inundation } \\
\text { depth }(\mathrm{m})\end{array}$ & $\begin{array}{r}\text { Number of } \\
\text { evacuation } \\
\text { floor }\end{array}$ & $\begin{array}{r}\text { Capacity } \\
\text { during } \\
\text { tsunami } \\
\text { (person) }\end{array}$ & $\begin{array}{r}\text { Inundation } \\
\text { depth }(\mathrm{m})\end{array}$ & $\begin{array}{r}\text { Number of } \\
\text { evacuation } \\
\text { floor }\end{array}$ & $\begin{array}{r}\text { Capacity } \\
\text { during } \\
\text { tsunami } \\
\text { (person) }\end{array}$ \\
\hline 1 & 10 & 1 & 2475 & 2475 & 0 & 1 & 2475 & 2.9 & 0 & 0 & 6 & 0 & 0 \\
\hline 2 & 20 & 5 & 3300 & 660 & 0.5 & 4 & 2640 & 3.9 & 3 & 1980 & 7 & 2 & 1320 \\
\hline 3 & 15 & 3 & 3300 & 1100 & 0 & 3 & 3300 & 1.4 & 2 & 2200 & 4.6 & 1 & 1100 \\
\hline 4 & 15 & 4 & 3300 & 825 & 0 & 4 & 3300 & 2.6 & 3 & 2475 & 5.7 & 2 & 1650 \\
\hline 5 & 10 & 3 & 1815 & 605 & 0 & 3 & 1815 & 0.1 & 2 & 1210 & 3.1 & 1 & 605 \\
\hline 6 & 20 & 4 & 3300 & 825 & 0 & 4 & 3300 & 0 & 4 & 3300 & 2.5 & 3 & 2475 \\
\hline 7 & 15 & 3 & 3300 & 1100 & 0 & 3 & 3300 & 0 & 3 & 3300 & 1.9 & 2 & 2200 \\
\hline 8 & 10 & 3 & 2310 & 770 & 0 & 3 & 2310 & 0.8 & 2 & 1540 & 3.6 & 1 & 770 \\
\hline 9 & 10 & 3 & 1650 & 550 & 0 & 3 & 1650 & 0.2 & 2 & 1100 & 3 & 2 & 1100 \\
\hline 10 & 10 & 3 & 4950 & 1650 & 0 & 3 & 4950 & 2.1 & 2 & 3300 & 5.1 & 1 & 1650 \\
\hline 11 & 47 & 2 & 6600 & 3300 & 0 & 2 & 6600 & 0 & 2 & 6600 & 2.2 & 1 & 3300 \\
\hline 12 & 15 & 3 & 2475 & 825 & 0 & 3 & 2475 & 0 & 3 & 2475 & 2.8 & 2 & 1650 \\
\hline 13 & 52 & 13 & 4950 & 381 & 0 & 13 & 4950 & 0.8 & 12 & 4569 & 4 & 11 & 4188 \\
\hline 14 & 15 & 4 & 8250 & 2063 & 0 & 4 & 8250 & 0 & 4 & 8250 & 3.1 & 2 & 4125 \\
\hline 15 & 10 & 3 & 4950 & 1650 & 0.3 & 2 & 3300 & 3.6 & 1 & 1650 & 6.7 & 0 & 0 \\
\hline 16 & 30 & 8 & 6600 & 825 & & & & & UNSAFE & & & & \\
\hline 17 & 15 & 5 & 5280 & 1056 & & & & & UNSAFE & & & & \\
\hline 18 & 20 & 4 & 5775 & 1444 & 0 & 4 & 5775 & 0.5 & 3 & 4331 & 3.8 & 2 & 2888 \\
\hline 19 & 10 & 2 & 1650 & 825 & 0 & 2 & 1650 & 0 & 2 & 1650 & 3 & 1 & 825 \\
\hline 20 & 22 & 5 & 6600 & 1320 & 1.3 & 4 & 5280 & 4 & 3 & 3960 & 6.8 & 2 & 2640 \\
\hline 21 & 25 & 6 & 4950 & 825 & 0 & 6 & 4950 & 0.3 & 5 & 4125 & 2.9 & 5 & 4125 \\
\hline 22 & 10 & 2 & 1650 & 825 & 0 & 2 & 1650 & 0.5 & 1 & 825 & 3.1 & 1 & 825 \\
\hline 23 & 25 & 6 & 6600 & 1100 & 0.5 & 5 & 5500 & 2.9 & 5 & 5500 & 5.6 & 4 & 4400 \\
\hline Total & capacity & & & & & & 79420 & & & 64340 & & & 41836 \\
\hline
\end{tabular}
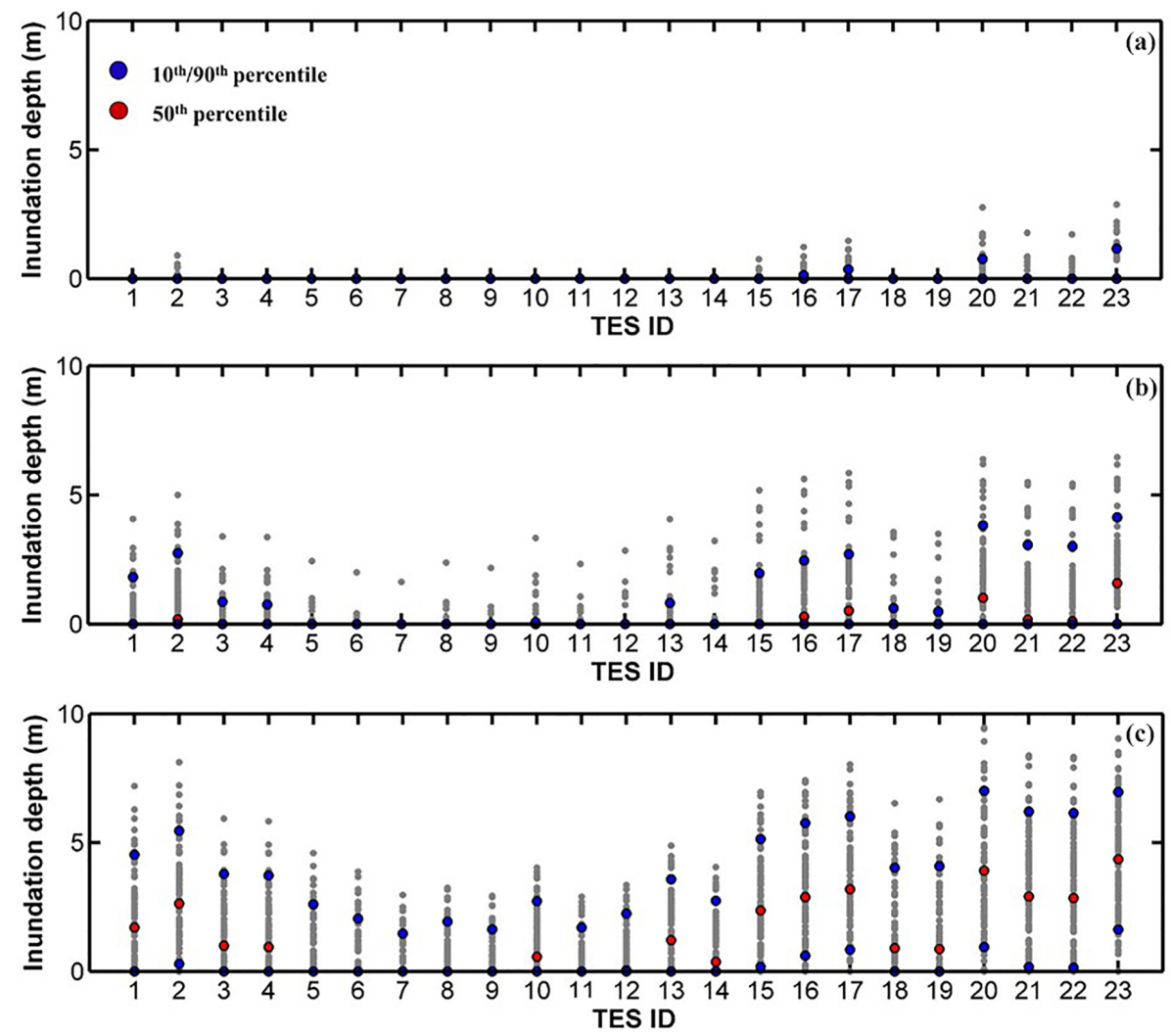

Figure 14. Inundation depth variability at TES stations for (a) $M_{\mathrm{W}} 8.5$ scenario, (b) $M_{\mathrm{W}} 8.75$ scenario, and (c) $M_{\mathrm{W}} 9.0$ scenario. 

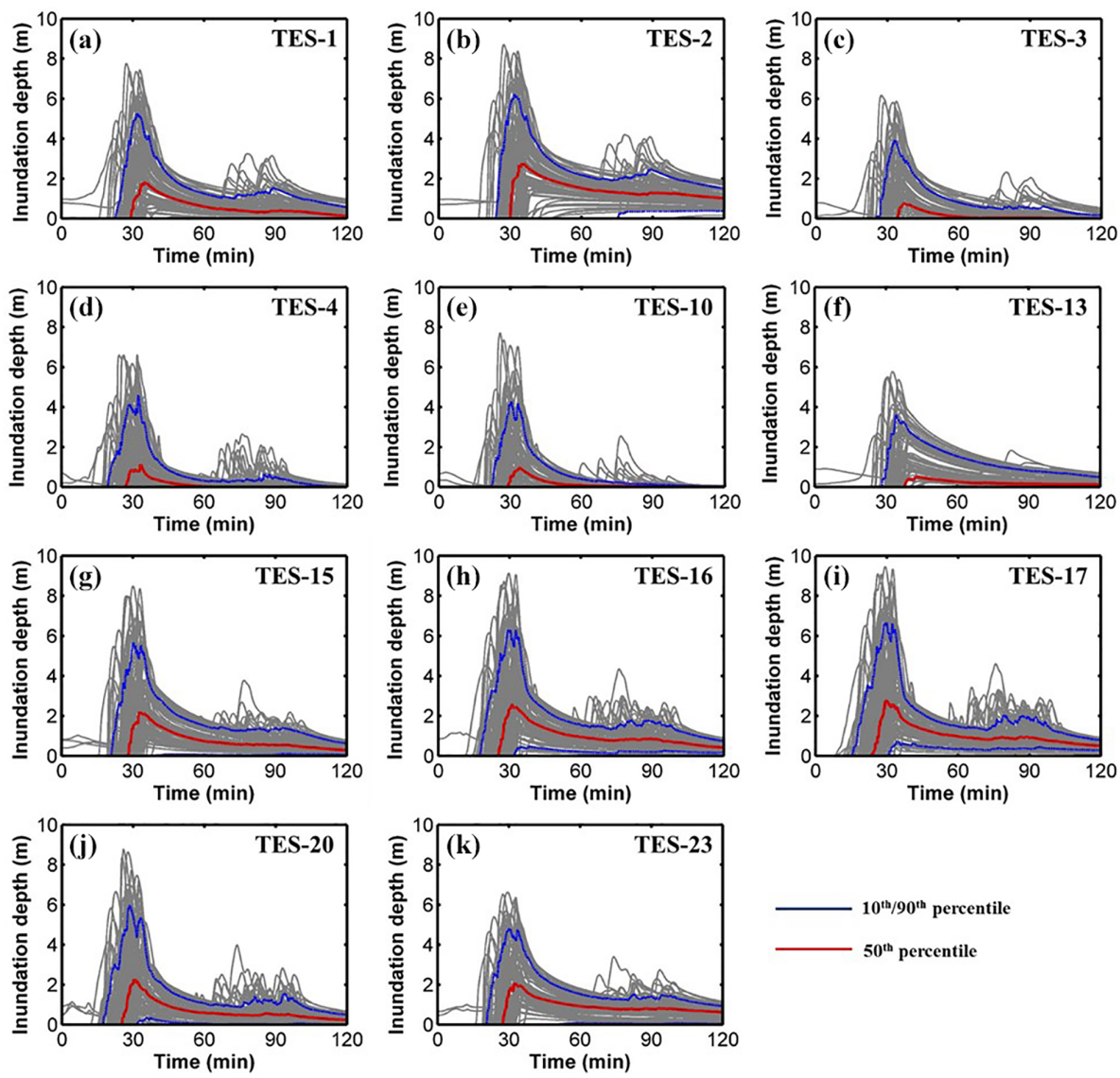

Figure 15. (a-k) Inundation depth variability at TES stations located near the coastal line and the rivers.

by the tsunami. Figure 15 shows that several stations (e.g., shelters 16, 17, and 20) are inundated by a maximum depth of nearly $10 \mathrm{~m}$ with the arrival times of about $15 \mathrm{~min}$ based on the 90th rank of the $M_{\mathrm{w}} 9.0$ scenario.

Second, the seismic vulnerability assessment results are carried out for the $M_{\mathrm{w}} 9.0$ scenario. To illustrate the seismic vulnerability assessment of TESs using HAZUS framework, the median ERS for the worst cases of the possible 100 earthquake scenarios (i.e., $M_{\mathrm{w}} 9.0$ and $R=55 \mathrm{~km}$ ) is shown in Fig. 16a. Note that this response spectrum does not include the inherent uncertainty associated with the earthquake ground motion simulation. The ADRS for this case is further calculated and shown as a blue line in Fig. 16b. Using the ADRS, the CSM is implemented to determine the performance (demand) point (Fig. 16b). After applying the reduction factors to obtain an inelastic seismic demand spectrum (green line in Fig. 16b), the performance point is estimated to be about 3 in. $(7.6 \mathrm{~cm})$ and then used to calculate the probability exceedance of damage states for a TES. Figure 16c shows that the sum of probabilities for extensive and complete damage states is $\sim 7 \%$ and thus the TES is considered to be safe for the median response spectra of the worst case.
The assessment that is illustrated in Fig. 16a-c ignores the inherent uncertainty of input ground motions. To account for this uncertainty, ground motion simulation results for 100 tsunamigenic earthquake scenarios are presented in Fig. 16d and e by considering the prediction error terms of the ground motion model together with inter-period correlations. The spectral acceleration profiles show a range of ground shaking that is expected to occur in Padang due to the 100 tsunamigenic earthquakes generated from the Mentawai segment of the Sunda subduction zone. The range of Sa in Padang is between 0.2 and $1.1 \mathrm{~g}$ for the period below $1 \mathrm{~s}$ (Fig. 16d). Moreover, the PGA (Fig. 16e) is within the interval of 0.3 to $0.9 \mathrm{~g}$ with a median of about $0.5 \mathrm{~g}$. Using the simulated response spectra from those 100 earthquake scenarios, the TES vulnerability is assessed. Figure $16 \mathrm{f}$ presents the three kinds of exceedance probability of damage states; blue dots correspond to extensive damage state, black dots correspond to complete damage state, and red dots represent the sum of these two probabilities. A $50 \%$ probability line is drawn to indicate the threshold of a safe building that is considered in this study. Figure 16f indicates that the TES may be operational for evacuation because $\sim 95 \%$ from the total of 100 earthquake simulations produce less than $50 \%$ exceedance probability 

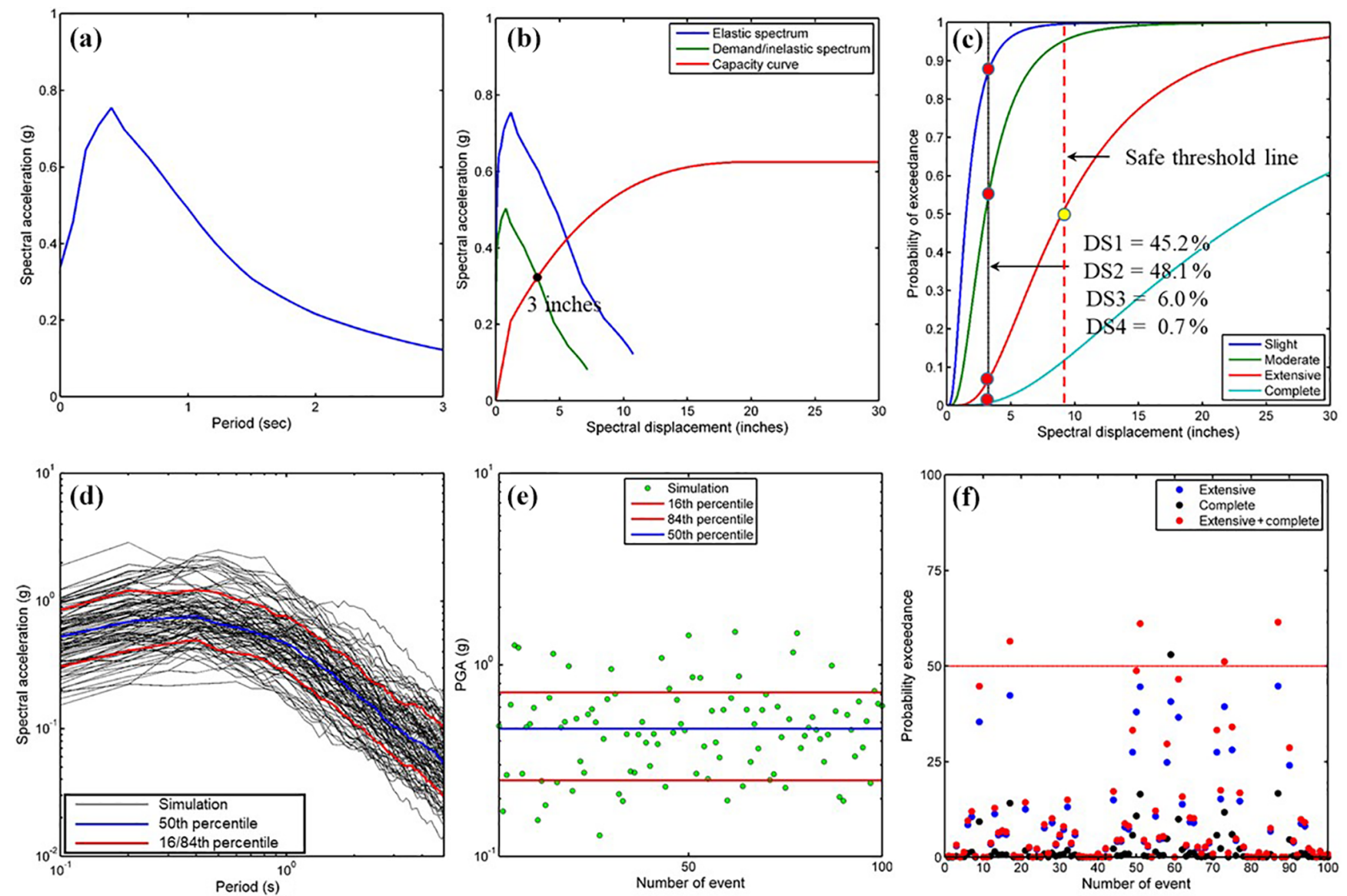

Figure 16. (a-c) The seismic vulnerability assessment of TES for the worst scenario using the HAZUS methodology. (d) Simulated spectral acceleration from the 100 tsunamigenic scenarios. (e) Simulated peak ground acceleration from the 100 tsunamigenic scenarios. (f) The probability exceedance of the three damage states from the 100 earthquake scenarios.

of the combined extensive-complete damage states. Moreover, most of the cases result in less than $25 \%$ probability of exceedance above the extensive damage state. Subsequently, the TES may be considered to be safe for evacuation after the ground shaking and, hence, the tsunami vulnerability assessment can be carried out.

Fourth, the tsunami vulnerability assessment is performed. Using the maximum inundation depths at all 23 TESs from the 100 earthquake scenarios of the $M_{\mathrm{w}} 9.0$, the probability of exceeding the severe damage state (DST3) for each TES is calculated. When the chance of severe tsunami damage exceeds $50 \%$, the TES is considered to be not usable as tsunami evaluation building. The probabilities of severe damage for the shelters 16 and 17 are relatively large, i.e., 30 and $36 \%$ of the 100 events, and thus these two shelters may be considered to be unsafe for the evacuation (see Table 5). Moreover, the probabilities of severe damage for the other shelters are relatively small (less than $25 \%$ ). Therefore, except for the shelters 16 and 17, the rest of the shelters are considered to be operational for evacuation.
Subsequently, the estimation of TES building capacity is evaluated. This may capture another point of view regarding the adequacy of existing TESs for evacuation. Table 6 presents the estimation of TES building capacity during the tsunami event considering the 10th percentile, the 50th percentile, and the 90th percentile. In terms of capacity, except for shelters 16 and 17, all TES buildings can be used for vertical evacuation during the 10th rank event. However, for the 50th percentile case, the shelter number 1 (sport center of UNP) may not be operational, whilst for the 90th percentile case shelters 1 and 15 (Elementary school of 24 Padang) are unable to accommodate evacuees since all floors will be inundated. Note that, for shelter number 1 , there is only one floor since most of the building areas are used for the sport arena. In terms of capacity, for the 50th and 90th rank cases, the possible maximum capacity to be accommodated at all TES buildings is only about 64000 and 41000 people, respectively. These numbers are insufficient in comparison to the total population in the coastal region of Padang (i.e., $\sim 200000$ people). Therefore, it is highly recommended to increase the number of TESs near the coastal areas in Padang. 

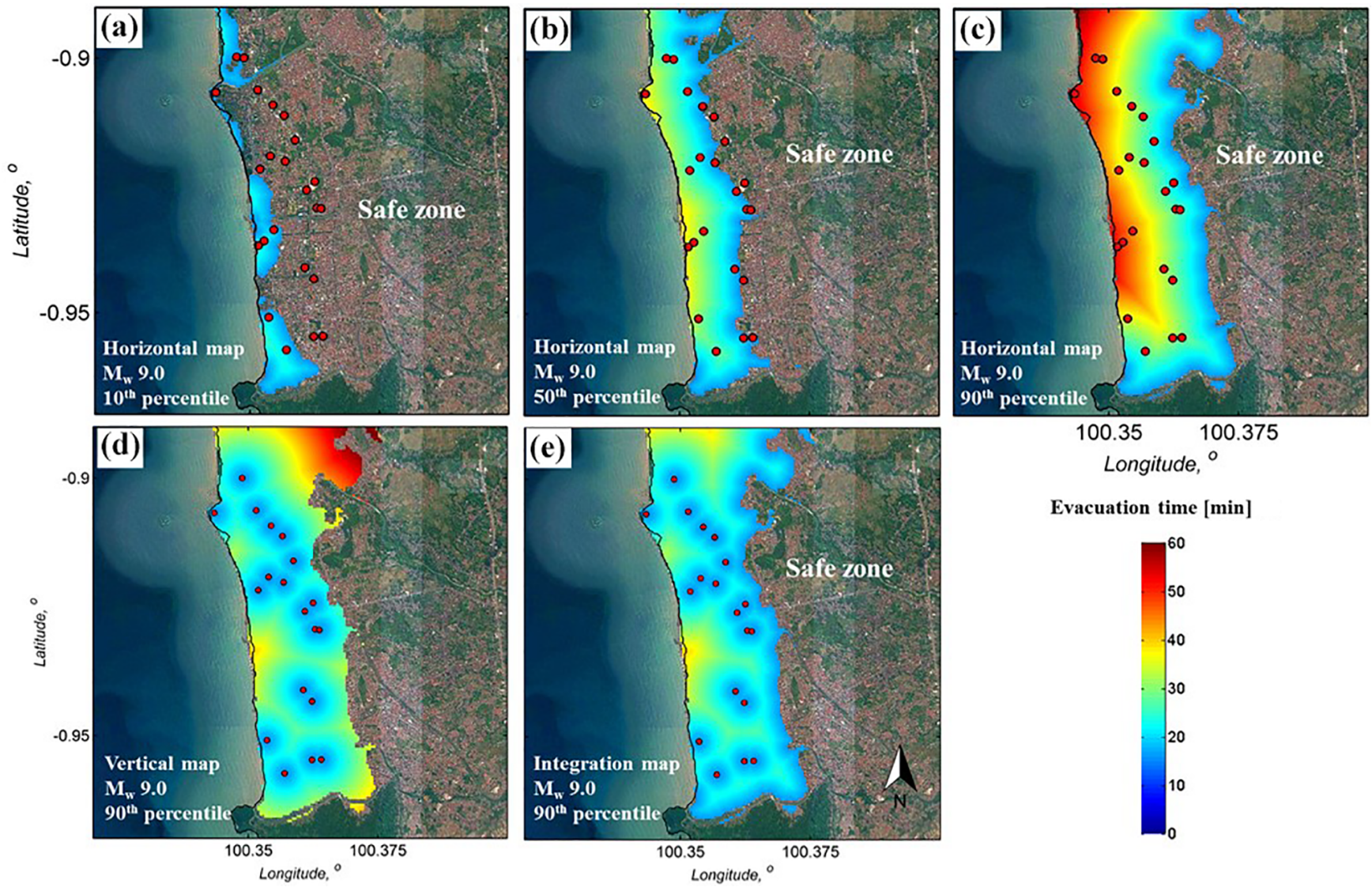

Evacuation time $[\mathrm{min}]$

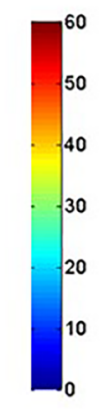

Figure 17. (a) Horizontal tsunami evacuation time maps in Padang for the 10th percentile. (b) Horizontal tsunami evacuation time maps in Padang for the 50th percentile. (c) Horizontal tsunami evacuation time maps in Padang for the 90th percentile. (d) Vertical tsunami evacuation time maps in Padang for the 90th percentile. (e) Integrated tsunami evacuation time maps in Padang for the 90th percentile.

Importantly, the TES assessment results highlight that the stochastic tsunami simulation method is able to capture the uncertainty of the future tsunamigenic impacts and thus is essential to use this method for developing an effective tsunami mitigation plan.

\subsection{Tsunami evacuation maps}

This section presents the tsunami evacuation maps based on the stochastic tsunami inundation depths in Padang. The developed tsunami evacuation maps consist of tsunami inundation maps and horizontal, vertical, and integrated evacuation time maps to the safe zones. Three scenarios are considered to develop tsunami evacuation time maps for the $M_{\mathrm{w}} 9.0$ scenario, i.e., the 10th percentile, the 50th percentile, and the 90th percentile. Note that the tsunami evacuation time maps developed in this section are based on the total evacuation time as presented in Sect. 2.2.4. The $M_{\mathrm{W}} 9.0$ scenario is chosen because it causes the most significant tsunami impacts in Padang (see inundation maps in Fig. 8).

Figure 8c shows tsunami inundation maps in Padang, whilst Fig. 17 illustrates tsunami evacuation time maps to the safe zones in Padang for the 10th percentile (Fig. 17a), the 50th percentile (Fig. 17b), and the 90th percentile (Fig. 17c). The horizontal tsunami evacuation time to the safe areas is calculated and is used to produce the tsunami evacuation time maps. The evacuation speed during the disaster event is chosen as $0.91 \mathrm{~m} \mathrm{~s}^{-1}$. The total evacuation time in the 10 th percentile case is sufficient to evacuate people from the coastal areas to the safe zone since the maximum evacuation time during this scenario event is about $25 \mathrm{~min}$ (see Fig. 17a). For the 50th percentile case, some people located closer to the coastal line may need more than $30 \mathrm{~min}$ for evacuation (see Fig. 17b). The most critical condition occurs in the case of the 90th percentile. A large population will need more than $50 \mathrm{~min}$ to evacuate to the safe zone and thus the vertical evacuation shelters are necessary to save the people residing in those areas.

Based on the TES assessment results, the vertical and integrated evacuation time maps are further developed to investigate the possibility of reducing evacuation time to the safe areas. Figure $17 \mathrm{~d}$ and e show the vertical and integrated tsunami evacuation time maps to the TES locations. The shelters 1, 15, 16, and 17 are excluded while vertical and 
integration tsunami evacuation time maps are developed because those shelters may be unsafe and inundated during the worst tsunamigenic event (the 90th percentile of the $M_{\mathrm{w}} 9.0$ scenario; see Sect. 3.2). In general, the vertical evacuation time map highlights that those shelters can only be accessed by the community located near the shelters (Fig. 17d). In addition, the integrated map shows that the availability of shelters is essential to save those residents in the critical regions (see Fig. 17e). Generally, by incorporating the vertical evacuation shelters and reducing the initial reaction time, the total evacuation time can be shorter. Therefore, besides increasing the number of TES buildings in Padang, large-scale tsunami evacuation drills in coastal community must be conducted to improve awareness of the tsunami hazard in Padang. Consequently, the casualties due to significant tsunamigenic events can be reduced.

\section{Conclusions and outlook}

The main purpose of this study was to develop effective tsunami evacuation plans in Padang based on the stochastic earthquake scenarios. Rigorous tsunami hazard assessments in Padang have been carried out using a novel stochastic tsunami simulation method to estimate the tsunami hazard level in Padang using three magnitude scenarios including $M_{\mathrm{W}} 8.5, M_{\mathrm{w}} 8.75$, and $M_{\mathrm{w}}$ 9.0. The stochastic earthquake scenarios were generated by adopting an asperity zone from the 1797 historical event and by considering the uncertainty and dependency of earthquake source parameters. For each magnitude, 100 stochastic earthquake source scenarios (300 models in total) were generated and implemented to run the Monte Carlo tsunami simulation. The assessment of tsunami hazard in Padang was then conducted based on the stochastic tsunami inundation depth (vertical relative distance from water free surface to ground). Subsequently, the vulnerability assessment of TESs considering the effects due to ground shaking and tsunami in Padang was carried out to evaluate the adequacy during the critical tsunami events. Finally, the hazard level assessment results were used to construct the tsunami inundation depth maps and tsunami evacuation time maps (i.e., horizontal, vertical, and integrated evacuation time maps) to better inform emergency response and rescue teams of current tsunami risks to residents in Padang. The evacuation time maps were developed for the three percentile levels (i.e., 10th, 50th, and 90th) of the $M_{\mathrm{w}} 9.0$ scenario.

For the $M_{\mathrm{W}} 9.0$ scenario, the tsunami inundation areas in Padang ranged from $4.27 \mathrm{~km}^{2}$ for the 10 th percentile to $19.43 \mathrm{~km}^{2}$ for the 90 th percentile with the maximum inundation depth reaching $10 \mathrm{~m}$. The results clearly demonstrated that Padang may face a significant impact of the tsunami in the case of the low-probability, high-consequence events. People who live near the coast will require about $60 \mathrm{~min}$ to evacuate to the safe zone (i.e., to inland high ground). In such situations, resistant vertical evacuation structures should be designed and constructed in the populated areas of Padang along the coast. The results from the seismic vulnerability assessment of the existing 23 TESs in Padang indicated that all TES buildings may be usable as emergency evacuation shelter during the ground shaking event prior to tsunami. However, shelters 16 and 17 are found to be unsafe during the worst tsunami event, whilst shelters 1 and 15 may not be operational because all floors are inundated. Therefore, the capacity may be insufficient to accommodate a large population in the coastal region and thus the number of TESs must be increased.

Lastly, although assessments for developing evacuation plans in Padang have been conducted in this study using the results of rigorous stochastic tsunami simulations, some limitations need to be addressed in future studies. These include (1) tsunami hazard simulations being conducted using highresolution DEM (e.g., $10 \mathrm{~m}$ ) and (2) other tsunami hazard parameters, e.g., flow velocity and momentum flux, as well as other tsunami evacuation parameters, e.g., population distribution and road access, being taken into account when assessing the adequacy of TESs in Padang.

Data availability. The bathymetry and elevation data for the Sumatra region were obtained from the GEBCO2014 database (http://www.gebco.net/data_and_products/gridded_ bathymetry_data/) (GEBCO, 2017), the SRTM1 database (https: //lta.cr.usgs.gov/SRTM1Arc) (USGS, 2017), and the GDEM2 database (https://asterweb.jpl.nasa.gov/gdem.asp) (GDEM2, 2017).

Competing interests. The authors declare that they have no conflict of interest.

Acknowledgements. The first author is grateful to the Directorate General of Resources for Science, Technology and Higher Education, Ministry of Research, Technology and Higher Education of Indonesia, which sponsored his $\mathrm{PhD}$ study. This work is also funded by the Engineering and Physical Sciences Research Council (EP/M001067/1). The authors are grateful to Sigit Sutikno, who provided the TES survey data in Padang.

Edited by: Ira Didenkulova

Reviewed by: Rachid Omira and one anonymous referee

\section{References}

Abrahamson, N., Gregor, N., and Addo, K.: BC hydro ground motion prediction equations for subduction earthquakes, Earthq. Spectra, 32, 23-44, https://doi.org/10.1193/051712EQS188MR, 2016.

Applied Technology Council: Seismic Evaluation and Retrofit of Concrete Buildings, Report ATC 40, Virginia, USA, November 1996. 
ASCE (American Society of Civil Engineers): Minimum design loads for buildings and other structures, American Society of Civil Engineers, Virginia, USA, 2006.

Aulia, Y. G.: Capacity assessment of tsunami evacuation shelters in Padang city, Thesis, Universitas Andalas, Padang, Indonesia, 2016 (in Bahasa).

Baker, J. W. and Cornell, C. A.: Correlation of response spectral values for multicomponent ground motions, B. Seismol. Soc. Am., 96, 215-227, 2006.

BAPPENAS: Master Plan for the rehabilitation and reconstruction of the regions and communities of the province of Nanggroe Aceh Darussalam and the Islands of Nias, Province of North Sumatera, BAPPENAS, Jakarta, 126 p., 2005.

Bazzurro, P., Cornell, C. A., Menun, C., and Motahari, M.: Advanced seismic assessment guidelines, Pacific Earthquake Engineering Research Center, Stanford University, Standford, CA, USA, 2006.

Borrero, J. C., Sieh, K., Chlieh, M., and Synolakis, C. E.: Tsunami inundation modeling for western Sumatra, P. Natl. Acad. Sci. USA, 103, 19673-19677, https://doi.org/10.1073/pnas.0604069103, 2006.

Briggs, R. W., Sieh, K., Meltzner, A. J., Natawidjaja, D., Galetzka, J., Suwargadi, B., Hsu, Y., Simons, M., Hananto, N., Suprihanto, I., Prayudi, D., Avouac, J. P., Prawirodirdjo, L., and Bock, Y.: Deformation and slip along the Sunda megathrust in the great 2005 Nias-Simeulue earthquake, Science, 311, 18971901. https://doi.org/10.1126/science.1122602, 2006.

Budiarjo, A.: Evacuation Shelter Building Planning for Tsunami Prone Area: a Case Study of Meulaboh City, Indonesia, ITC, Enschede, 112 p., 2006.

Casarotti, C., Monteiro, R., and Pinho, R.: Verification of spectral reduction factors for seismic risk assessment of bridges, New Zealand Nat. Soc. Earthquake Eng. Bull., 42, 111-121, 2009.

Charnkol, T. and Tanaboriboon, Y.: Tsunami evacuation behavior analysis: one step of transportation disaster Response, IATSS Res., 30, 83-96, 2006.

Charvet, I., Macabuag, J., and Rossetto, T.: Estimating tsunamiinduced building damage through fragility functions: critical review and research needs, Front. Built Environ., 3, 1-22, https://doi.org/10.3389/fbuil.2017.00036, 2017.

Chlieh, M., Avouac, J. P., Sieh, K., Natawidjaja, D. H., and Galetzka, J.: Heterogeneous coupling of the Sumatran megathrust constrained by geodetic and paleogeodetic measurements, J. Geophys. Res.-Sol. Ea., 113, B05305, 1-31, https://doi.org/10.1029/2007JB004981, 2008.

Dewi, R. S.: A-Gis Based approach of an evacuation model for tsunami risk reduction, IDRiM J., 2, 108-139, https://doi.org/10.5595/idrim.2012.0023, 2012.

Dias, W. P. S., Yapa, H. D., and Peiris, L. M. N.: Tsunami vulnerability functions from field surveys and Monte Carlo simulation, Civ. Eng. Environ. Syst., 26, 181-194, https://doi.org/10.1080/10286600802435918, 2009.

FEMA (Federal Emergency Management Agency): Pre-Standard and Commentary for the Seismic Rehabilitation of Buildings (FEMA 356), Federal Emergency Management Agency, Washington, D. C., USA, 2000.

FEMA (Federal Emergency Management Agency): NEHRP Recommended Seismic Provisions for New Buildings and Other
Structures (FEMA P-750), Federal Emergency Management Agency, Washington, D. C., USA, 2009.

FEMA (Federal Emergency Management Agency): Guidelines for Design of Structures for Vertical Evacuation from Tsunamis (FEMA P-646 second ed.), Federal Emergency Management Agency, Washington, D. C., USA, 2012.

Freeman, S. A.: Review of the development of the capacity spectrum method, ISET J. Earth Tech., 41, 1-13, 2004.

Gallegos, H. A., Schubert, J. E., and Sanders, B. F.: Two-dimensional, high-resolution modeling of urban dam-break flooding: a case study of Baldwin Hills, California, Adv. Water Resour., 32, 1323-1335, https://doi.org/10.1016/j.advwatres.2009.05.008, 2009.

GDEM2: GDEM2 data, available at: https://asterweb.jpl.nasa.gov/ gdem.asp, last access: 1 December 2017.

GEBCO: Bathymetry and elevation data for the Sumatra region, available at: http://www.gebco.net/data_and_products/gridded_ bathymetry_data/, last access: 1 December 2017.

Goda, K. and Atkinson, G. M.: Probabilistic characterization of spatially correlated response spectra for earthquakes in Japan, B. Seismol. Soc. Am., 99, 3003-3030, 2009.

Goda, K., Mai, P. M., Yasuda, T., and Mori, N.: Sensitivity of tsunami wave profiles and inundation simulations to earthquake slip and fault geometry for the 2011 Tohoku earthquake, Earth Planets Space, 66, 105, https://doi.org/10.1186/1880-5981-66105, 2014.

Goda, K., Yasuda, T., Mori, N., and Maruyama, T.: New scaling relationships of earthquake source parameters for Stochastic Tsunami Simulation, Coast. Eng. J., 58, 1-40, https://doi.org/10.1142/S0578563416500108, 2016.

Goseberg, N. and Schulrmann, T.: Tsunami hazard mapping and risk assessment for the city of Padang/West Sumatra, Meeting of Disaster Risk Reduction for Natural Hazard, London, November 2009, available at: http://www.ucl.ac. uk/drrconference/presentations/TSchlurmann.pdf (last access: 1 July 2017), 2009.

Goto, C., Ogawa, Y., Shuto, N., and Imamura, F.: Numerical Method of Tsunami Simulation with the Leap-Frog Scheme, IOC Manual, UNESCO, Paris, France, 35, 1997.

Griffin, J., Latief, H., Kongko, W., Harig, S., Horspool, N., Hanung, R., Rojali, A., Maher, N., Fuchs, A., Hossen, J., Upi, S., Edi, Dewanto, S., Rakowsky, N., and Cummins, P.: An evaluation of onshore digital elevation models for modeling tsunami inundation zones, Front. Earth Sci., 3, 32, https://doi.org/10.3389/feart.2015.00032, 2015.

Griffin, J. D., Pranantyo, I. R., Kongko, W., Haunan, A., Robiana, R., Miller, Davies, G., Horspool, N., Maemunah, I., Widjaja, W. B., Natawidjaja, D. H., and Latief, H.: Assessing tsunami hazard using heterogeneous slip models in the Mentawai Islands, Indonesia, in: Geohazards in Indonesia: Earth Science for Disaster Risk Reduction, edited by: Cummins, P. R. and Meilano, I., Special Publications, Geological Society, London, UK, 441, https://doi.org/10.1144/SP441.3, 2016.

Hayes, G. P., Wald, D. J., and Keranen, K.: Advancing techniques to constrain the geometry of the seismic rupture plane on subduction interfaces a priori - higher order functional fits, Geochem. Geophy. Geosy., 10, Q09006, https://doi.org/10.1029/2009GC002633, 2009. 
Hayes, G. P., Wald, D. J., and Johnson, R. L.: Slab1.0, a three-dimensional model of global subduction zone geometries, J. Geophys. Res.-Sol. Ea., 117, B01302, https://doi.org/10.1029/2011JB008524, 2012.

HAZUS: Multi-Hazard Loss Estimation Methodology Earthquake Model, Federal Emergency Management Agency, Washington, D. C., USA, 2003.

Imamura, F., Muhari, A., Mas, E., Pradono, M. H., Post, J., and Sugimoto, M.: Tsunami disaster mitigation by integrating comprehensive countermeasures in Padang City, Indonesia, J. Disaster Res., 7, 48-64, 2011.

Iwasaki, T. and Mano, A.: Two-dimensional numerical computation of tsunami run ups in Eulerian description, Proc. of 26th Conference on Coastal Engineering, Japan, JSCE, 70-74, 1979.

Kazama, M. and Noda, T.: Damage statistics (Summary of the 2011 off the Pacific Coast of Tohoku Earthquake damage), Soils Found., 52, 780-792, https://doi.org/10.1016/j.sandf.2012.11.003, 2012.

Kim, H., Min, K., Chung, L., Park, M., and Lee, S.: Evaluation of capacity spectrum method for estimating the peak inelastic responses, J. Earthq. Eng., 9, 695-718, 2005.

Konca, A. O., Hjorleifsdottir, V., Song, T. A., Avouac, J. P., Helmberger, D. V., Ji, C., Sieh, K., Briggs, R., and Meltzner, A.: Rupture kinematics of the 2005, Mw 8.6, Nias-Simeulue earthquake from the joint inversion of seismic and geodetic data, B. Seismol. Soc. Am., 97, S307-S322, https://doi.org/10.1785/0120050632, 2007.

Koshimura, S., Oie, T., Yanagisawa, H., and Imamura, F.: Developing fragility functions for tsunami damage estimation using numerical model and post-tsunami data from Banda Aceh, Indonesia, Coast. Eng. J., 51, 243-273, https://doi.org/10.1142/S0578563409002004, 2009.

Kulmesch, S.: Evaluation of the HAZUS-MH loss estimation methodology for a natural risk management case study in Carinthia, Austria, Master Thesis, Carinthia University of Applied Sciences, Carinthia, Austria, 2010.

Kurniawan, A. A., Sutikno, S., and Rinaldi: Evaluasi Kapasitas Shelter Evakuasi Untuk Bencana Tsunami Di Kota Padang Berbasis Sistem Imformasi Geografis (SIG), Journal Online Mahasiswa, 1, 1-9, 2014.

Lewis, M., Bates, P., Horsburgh, K., Neal, J., and Schumann, G.: A storm surge inundation model of the northern Bay of Bengal using publicly available data. Q. J. Roy. Meteor. Soc., 139, 358369, https://doi.org/10.1002/qj.2040, 2013.

Lin, Y. Y. and Chang, K. C.: An improved capacity spectrum method for ATC-40, Earthq. Eng. Struct. D., 32, 2013-2025, 2003.

Mai, P. M. and Beroza, G. C.: Source scaling properties from finitefault-rupture models, B. Seismol. Soc. Am., 85, 1348-1357, https://doi.org/10.1785/0220140077, 2000.

Mai, P. M. and Beroza, G. C.: A spatial random field model to characterize complexity in earthquake slip, J. Geophys. Res.-Sol. Ea., 107, ESE 10-1-ESE 10-21, https://doi.org/10.1029/2001JB000588, 2002.

Meltzner, A. J., Sieh, K., Abrams, M., Agnew, D. C., Hudnut, K. W., Avouac, J. P., and Natawidjaja, D. H.: Uplift and subsidence associated with the great Aceh-Andaman earthquake of 2004, J.-Geophys. Res.-Sol. Ea., 111, B02407, https://doi.org/10.1029/2005JB003891, 2006.
McCloskey, J., Antonioli, A., Piatanesi, A., Sieh, K., Steacy, S., Nalbant, S., Coccob, M., Giunchib, C., Huanga, J. D., and Dunlop, P.: Tsunami threat in the Indian Ocean from a future megathrust earthquake west of Sumatra, Earth Planet. Sc. Lett., 265, 6181, https://doi.org/10.1016/j.eps1.2007.09.034, 2008.

McGuire, E. K.: Deterministic vs. probabilistic earthquake hazards and risks, Soil. Dyn. Earthq. Eng., 21, 377-384, https://doi.org/10.1016/S0267-7261(01)00019-7, 2001.

MLITT (Japanese Ministry of Land Infrastructure Tourism and Transport): Concerning Setting the Safe Structure Method for Tsunamis Which Are Presumed When Tsunami Inundation Occurs - Public Notice 1318, Ministry of Land, Infrastructure, Transportation and Tourism, Tokyo, Japan, 2013 (in Japanese).

Monteiro, R., Marques, M., Adhikari, G., Casarotti, C., and Pinho, R.: Spectral reduction factors evaluation for seismic assessment of frame buildings, Eng. Struct., 77, 129-142, 2014.

Mori, N., Takahashi, T., Yasuda, T., and Yanagisawa, H.: Survey of 2011 Tohoku Earthquake Tsunami Inundation and Run-Up, Geophys. Res. Lett., 38, L00G14, https://doi.org/10.1029/2011GL049210, 2011.

Mori, N., Muhammad, A., Goda, K., Yasuda, T., and RuizAngulo, A.: Probabilistic tsunami hazard analysis of the Pacific Coast of Mexico: case study based on the 1995 Colima earthquake tsunami, Front. Built Environ., 3, 1-16, https://doi.org/10.3389/fbuil.2017.00034, 2017.

Muhammad, A., Goda, K., and Alexander, N.: Tsunami hazard analysis of future megathrust Sumatra earthquakes in Padang, Indonesia using stochastic tsunami simulation, Front. Built Environ., 2, 33, 1-19, https://doi.org/10.3389/fbuil.2016.00033, 2016.

Muhari, A., Imamura, F., Natawidjaja, D. H., Diposaptono, S., Latief, H., Post, J., and Ismail, F. A.: Tsunami mitigation efforts with pTA in West Sumatra Province, Indonesia, J. Earthq. Tsunami, 4, 341-368, https://doi.org/10.1142/S1793431110000790, 2010.

Muhari, A., Imamura, F., Koshimura, S., and Post, J.: Examination of three practical run-up models for assessing tsunami impact on highly populated areas, Nat. Hazards Earth Syst. Sci., 11, 31073123, https://doi.org/10.5194/nhess-11-3107-2011, 2011.

Mueller, C., Power, W., Fraser, S., and Wang, X.: Effects of rupture complexity on local tsunami inundation: implications for probabilistic tsunami hazard assessment by example, J. Geophys. Res.Sol. Ea., 120, 488-502, https://doi.org/10.1002/2014JB011301, 2015.

Nalbant, S. S., Steacy, S., Sieh, K., Natawidjaja, D., and McCloskey, J.: Seismology: earthquake risk on the Sunda trench, Nature, 435, 756-757, https://doi.org/10.1038/nature435756a, 2005.

Natawidjaja, D. H., Sieh, K., Chlieh, M., Galetzka, J., Suwargadi, B. W., Cheng, H., Edwards, R. L., Avouac, J. P., and Ward, S. N.: Source parameters of the great Sumatran megathrust earthquakes of 1797 and 1833 inferred from coral microatolls, J. Geophys. Res.-Sol. Ea., 111, B06403, https://doi.org/10.1029/2005JB004025, 2006.

Newman, A. V., Hayes, G., Wei, Y., and Convers, J.: The 25 October 2010 Mentawai tsunami earthquake, from real-time discriminants, finite-fault rupture, and tsunami excitation, Geophys. Res. Lett., 38, 1-7, https://doi.org/10.1029/2010GL046498, 2011. 
Okada, Y.: Surface deformation due to shear and tensile faults in a half-space. B. Seismol. Soc. Am., 75, 1135-1154, 1985.

Peterson, J. and Small, M. J.: Methodology for benefitcost analysis of seismic codes, Nat. Hazards, 63, 1039, https://doi.org/10.1007/s11069-012-0204-7, 2012.

Philibosian, B., Sieh, K., Avouac, J. P., Natawidjaja, D. H., Chiang, H., Wu, C., Perfettini, H., Shen, C. C., Daryono, M. R., and Suwargadi, B. W.: Rupture and variable coupling behavior of the Mentawai segment of the Sunda megathrust during the super cycle culmination of 1797 to 1833 , J. Geophys. Res.-Sol. Ea., 119, 7258-7287, https://doi.org/10.1002/2014JB011200, 2014.

Post, J., Wegscheider, S., Mück, M., Zosseder, K., Kiefl, R., Steinmetz, T., and Strunz, G.: Assessment of human immediate response capability related to tsunami threats in Indonesia at a sub-national scale, Nat. Hazards Earth Syst. Sci., 9, 1075-1086, https://doi.org/10.5194/nhess-9-1075-2009, 2009.

Putra, R. R., Kiyono, J., and Furukawa, A.: Vulnerability assessment of non engineered houses based on damaga state data of the 2009 Padang earthquake in Padang City, Indonesia, Int. J. of GEOMATE, 7, 1076-1083, available at: https://www.waset.org/downloads/temp/ vulnerability-of-non-engineere-structure-rusnardi-usa-2014-. pdf (last access: 10 July 2017), 2014.

Raby, A., Macabuag, J., Pomonis, A., Wilkinson, S., and Rossetto, T.: Implications of the 2011 Great East Japan Tsunami on sea defence design, Int. J. Disast. Risk. Re., 14, 332-336, https://doi.org/10.1016/j.ijdrr.2015.08.009, 2015.

Rossetto, T. and Elnashai, A.: Derivation of vulnerability functions for European-type RC structures based on observational data, Eng. Struct., 25, 1241-1263, 2003.

Sanders, B. F.: Evaluation of on-line DEMs for flood inundation modeling, Adv. Water Resour., 30, 1831-1843, https://doi.org/10.1016/j.advwatres.2007.02.005, 2007.

Satake, K., Nishimura, Y., Putra, P. S., Gusman, A. R., Sunendar, H., Fujii, Y., Sunendar, H., Latief, H., and Yulianto, E.: Tsunami source of the 2010 Mentawai, Indonesia earthquake inferred from tsunami field survey and waveform modeling, Pure Appl. Geophys., 170, 1567-1582, https://doi.org/10.1007/s00024-0120536-y, 2013.

Satge, F., Bonnet, M. P., Timouk, F., Calmant, S., Pillco, R., Molina, W., Lavado-Casimiro, Arsen, A., Crétaux, J. F., and Garnier, J.: Accuracy assessment of SRTM v4 and ASTER GDEM v2 over the Altiplano watershed using ICESat/GLAS data, Int. J. Remote Sens., 36, 2, 465-88, 2015.

Sengara, I. W., Sidi, I. D., Mulia, A., Muhammad, A., and Daniel, H.: Development of risk coefficient for input to new Indonesian seismic building codes, J. Eng. Tech. Sci., 48, 49-65, 2016.

Scheer, S. J., Gardi, A., Guillande, R., Eftichidis, G., Varela, V., de Vanssay., B., and Colbeau-Justin., L.: Handbook of tsunami evacuation planning, JCR Scientific and Technical Reports, European Union, Luxembourgh City, Luxembourgh, 2011.

Scheer, S. J., Varela, V., and Eftychidis, G.: A generic framework for tsunami evacuation planning, Phys. Chem. Earth, 49, 79-91, https://doi.org/10.1016/j.pce.2011.12.001, 2012.

Schlurmann, T., Kongko, W., Goseberg, N., Natawidjaja, D. H., and Sieh, K.: Near-field tsunami hazard map padang, west sumatra: utilizing high resolution geospatial data and reasonable source scenarios, Coast. Eng., 32, 1-17, https://doi.org/10.9753/icce.v32.management.26, 2010.

Sieh, K., Natawidjaja, D. H., Meltzner, A. J., Shen, C. C., Cheng, H., Li, K. S., Suwargadi, B. W., Galetzka, J., Philibosian, B., and Edwards, R. L.: Earthquake super cycles inferred from sea-level changes recorded in the corals of West Sumatra, Science, 322, 1674-1678, https://doi.org/10.1126/science.1163589, 2008.

SNI 03-1726-2002: Standar Perencanaan Ketahanan Gempa untuk Struktur Bangunan Gedung, Badan Standarisasi Nasional, Jakarta, Indonesia, 2002 (in Bahasa).

SNI 03-1726-2012: Tata cara perencaan ketahanan gempa untuk gedung, Badan Standarisasi Nasional, Jakarta, Indonesia, 2012 (in Bahasa).

Suppasri, A., Koshimura, S., and Imamura, F.: Developing tsunami fragility curves based on the satellite remote sensing and the numerical modeling of the 2004 Indian Ocean tsunami in Thailand, Nat. Hazards Earth Syst. Sci., 11, 173-189, https://doi.org/10.5194/nhess-11-173-2011, 2011.

Suppasri, A., Charvet, I., Imai, K., and Imamura, F.: Fragility curves based on data from the 2011 Great East Japan tsunami in Ishinomaki city with discussion of parameters influencing building damage, Earthq. Spectra, 31, 841-868, https://doi.org/10.1193/053013EQS138M, 2014.

Tachikawa, T., Kaku, M., Iwasaki, A., and Hato, M.: Characteristics of ASTER GDEM Version 2. IEEE Int. Geosci. Remote Sens. Symp. (IGARRS 2011), Vancouver, Canada, 1-4, 2011.

Tanaka, H., Kayane, K., Adityawan, M. B., Roh, M., and Farid, M.: Study on the Relation of River Morphology and Tsunami Propagation in Riversm, Ocean Dynam., 64, 1319-1332, 2014.

Tanioka, Y. and Satake, K.: Tsunami generation by horizontal displacement of ocean bottom, Geophys. Res. Lett., 23, 861-864, 1996.

Taubenböck, H., Goseberg, N., Setiadi, N., Lämmel, G., Moder, F., Oczipka, M., Klüpfel, H., Wahl, R., Schlurmann, T., Strunz, G., Birkmann, J., Nagel, K., Siegert, F., Lehmann, F., Dech, S., Gress, A., and Klein, R.: "Last-Mile" preparation for a potential disaster - Interdisciplinary approach towards tsunami early warning and an evacuation information system for the coastal city of Padang, Indonesia, Nat. Hazards Earth Syst. Sci., 9, 15091528, https://doi.org/10.5194/nhess-9-1509-2009, 2009.

United States Geological Survey (USGS): Latest earthquakes, available at: http://earthquake.usgs.gov/earthquakes/map/, last access: 1 December 2015.

United States Geological Survey (USGS): SRTM 1 Arc-Second Global elevation data, available at: https://lta.cr.usgs.gov/ SRTM1Arc, last access: 1 December 2017.

Widyaningrum, E.: Tsunami Evacuation Planning Using Geoinformation Technology Considering Land Management Aspects, Case Study: Cilacap, Central of Java, Centre of Land and Environmental Risk Management, Technische Universität München, Munich, Germany, 87 pp., 2009.

Wijayanti, E., Kristiawan, S. A., Purwanto, E., and Sangadji, S. Seismic vulnerability of $\mathrm{R}=$ reinforced concrete building based on the development of fragility curve: a case study, Appl. Mech. Mater., 845, 252-258, 2015.

Wood, N. J. and Schmidtlein, M. C.: Anisotropic path modeling to assess pedestrian-evacuation potential from Cascadia-related 
tsunamis in the US Pacific Northwest, Nat. Hazards, 62, 275300, https://doi.org/10.1007/s11069-011-9994-2, 2012.

Wood, N. J., Jones, J., Schelling, J., and Schmidtlein, M. C.: Tsunami vertical-evacuation planning in the US Pacific Northwest as a geospatial, multi-criteria decision problem, Int. J. Disast. Risk. Re., 9, 68-83, 2014.

Yue, H., Lay, T., Rivera, L., Bai, Y., Yamazaki, Y., Cheung, K. F., Hill, E. M., Sieh, K., Kongko, W., and Muhari, A.: Rupture process of the $2010 \mathrm{Mw} 7.8$ Mentawai tsunami earthquake from joint inversion of near-field hr-GPS and teleseismic body wave recordings constrained by tsunami observations, J. Geophys. Res.-Sol. Ea., 119, 5574-5593, https://doi.org/10.1002/2014JB011082, 2014.
Zachariasen, J., Sieh, K., Taylor, F. W., Edwards, R. L., and Hantoro, W. S.: Submergence and uplift associated with the giant 1833 Sumatran subduction earthquake: evidence from coral microatolls, J. Geophys. Res.-Atmos., 104, 895-919, 1999. 